\author{
Randall H. McGuire
}

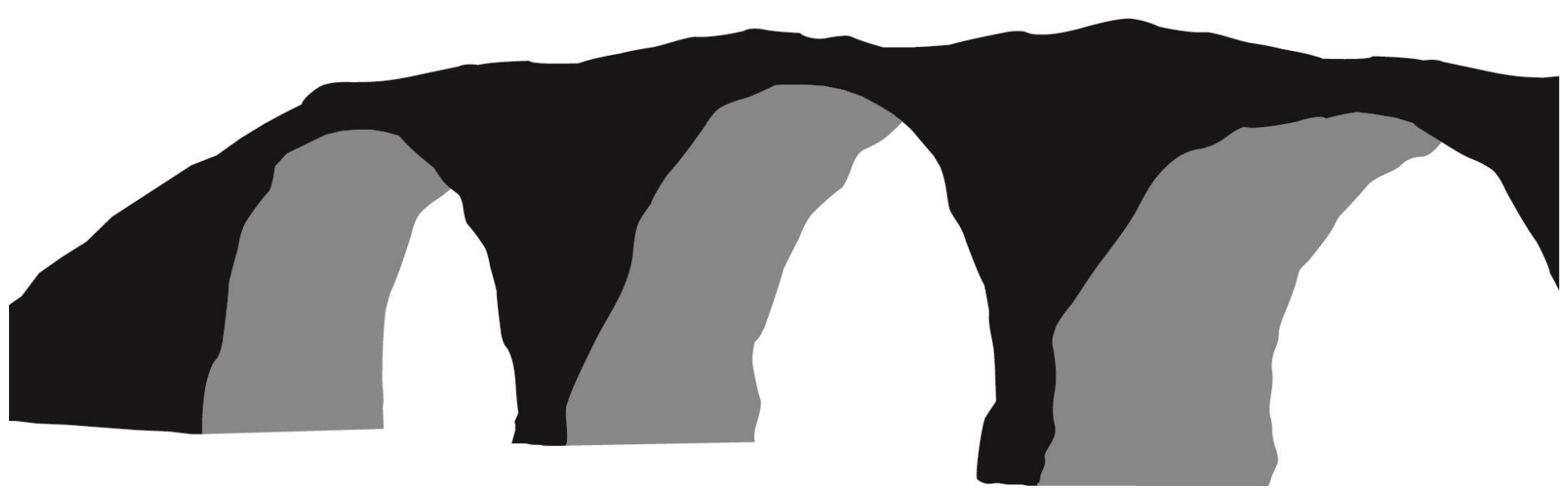




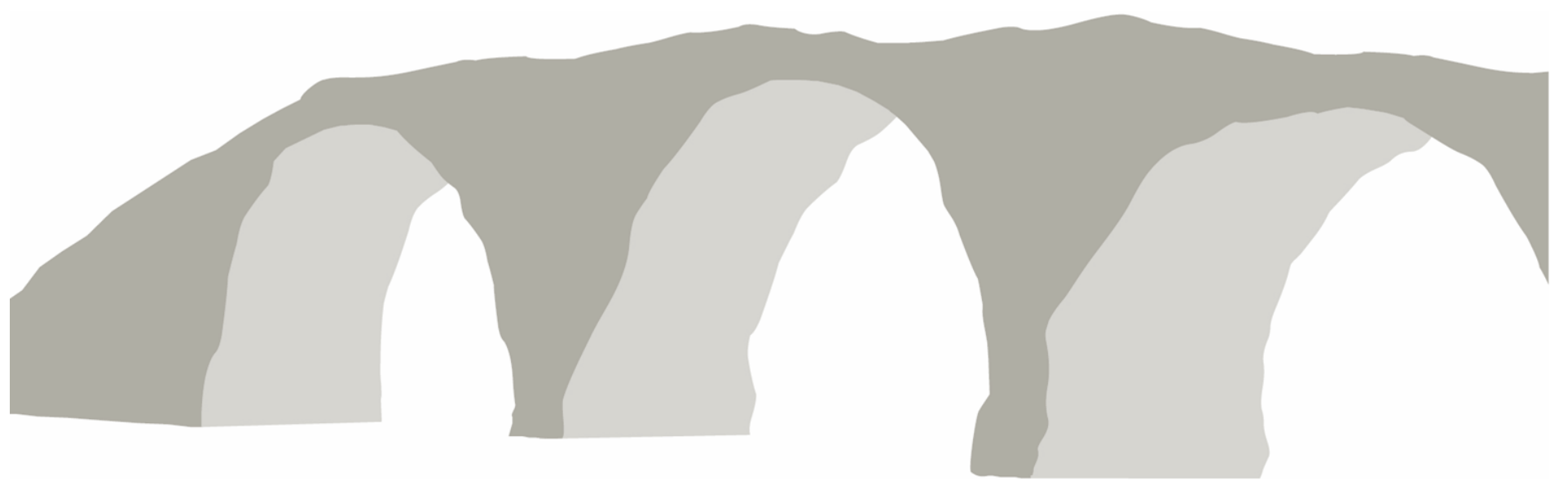




\title{
DIÁLOGOS CON LOS MUERTOS. IDEOLOGÍA Y CEMENTERIO ${ }^{1}$
}

\section{DIALOGUES WITH THE DEAD. IDEOLOGY AND THE CEMETERY}

\author{
Randall H. McGuire
}

Lo sabes, si vivir fuera algo que el dinero pudiera comprar, los ricos vivirían y los pobres morirían Balada tradicional

Esta frase de una balada tradicional resalta dos puntos centrales de este trabajo. La primera es que la inmortalidad es deseable y la segunda es que el poder afectará la distribución de las cosas deseables, especialmente si estas cosas se pueden comprar y vender. Algunas personas han buscado la inmortalidad mediante el entierro y la conmemoración, y en diferentes momentos de la historia humana hemos sido testigos de las grandes diferencias que las personas han tenido al acceso a tal inmortalidad.

Los arqueólogos están acostumbrados a asumir una relación directa entre la inversión funeraria y el estatus social (Binford, 1971; Saxe, 1970; Tainter, 1978; O’Shea, 1984; Bartel, 1982). Muchos han supuesto que los ricos siempre han adquirido para sí las formas de exhibición mortuoria más suntuosas. Para estos investigadores, el ritual mortuorio, la forma de enterramiento, el ajuar funerario y los monumentos reflejan directamente la dimensión social, que a su vez es el resultado de las relaciones materiales que determinaron el nivel evolutivo de la cultura.

Recientemente, un número cada vez mayor de investigadores han rechazado la conceptualización del ritual funerario como algo determinado y en ningún caso determinante, y en su lugar han ubicado al ritual mortuorio en el ámbito de la ideología (Hodder, 1982; Pearson, 1982; Shanks \& Tilley, 1982; Miller \& Tilley, 1984; Kristiansen, 1984). Ellos consideran al análisis de los restos mortuorios como un caso particular dentro del estudio más general sobre cómo la ideología legitima el orden social. Ellos destacan el poder y las anomalías entre los poderosos y los que carecen de poder en las sociedades como una dinámica interna para el cambio cultural. Como ideología, el ritual funerario no se refiere necesariamente a las relaciones reales de poder en una sociedad, sino a una expresión idealizada de estas relaciones. El ritual actúa ideológicamente para mantener el orden social al distorsionar la verdadera naturaleza de las relaciones sociales. El ritual funerario es, por lo tanto, una parte activa de la negociación y la lucha entre los poderosos y los que carecen de poder en la sociedad.

Mi propósito inicial al estudiar las lápidas de los últimos 180 años en el condado de Broome, Nueva York, fue determinar si proporcionaban un reflejo directo de la estratificación social en la comunidad. Luego de un breve examen, fue evidente que en algunos períodos temporales sí lo hacían y en otros no. El supuesto de que reflejan directamente el orden social dentro de una única etapa evolutiva claramente no se confirma. Más importante aún, la respuesta a mi pregunta inicial planteó temas mucho más fascinantes que la investigación original.

\footnotetext{
${ }^{1}$ Traduzido com permissão do autor. Tradução Romina C. Rigone. Facultad de Filosofía y Letras, Universidad de Buenos Aires, Buenos Aires, Argentina. rominarigone@hotmail.com.

${ }^{2}$ Department of Anthropology, Binghamton University, Binghamton, New York. rmcguire@binghamton.edu.
} 
Los muertos hablan en los cementerios del condado de Broome a través de los monumentos conmemorativos que han construido. Los muertos, o sus parientes, erigieron estos monumentos como expresiones deliberadas de sus ideales en relación a la muerte, clase y familia. Ellos estaban diseñados para establecer y perpetuar un diálogo con los vivos, un diálogo que los muertos esperaban que reforzara las creencias y la cosmovisión que llevaban a sus tumbas. Sin embargo, éste fue un diálogo sostenido por los vivos, por lo que tomó formas y direcciones no planeadas por los difuntos.

El progreso de este diálogo en el condado de Broome desde el siglo XIX hasta el presente revela un cambio fundamental en la cultura e ideología del capitalismo. Este cambio se produjo a comienzos del siglo $\mathrm{XX}$ y creó los supuestos que utilizamos para darle sentido a nuestro mundo. El cambio implicó un desplazamiento desde la mistificación basada en la naturalización a una negación de las desigualdades y las relaciones de poder.

\section{IDEOLOGÍA}

El concepto clave en mi análisis es la ideología. Utilizo un concepto derivado del marxismo que es bastante diferente de la definición de ideología comúnmente utilizada en la arqueología y el materialismo cultural (Binford, 1962; White, 1959). El marxismo contemporáneo trata a la ideología como un componente activo de la lucha entre los poderosos y los que carecen de poder, antes que como una consecuencia del cambio tecnológico y social. La mayoría de los intentos arqueológicos por localizar el ritual funerario en el ámbito de la ideología han tratado a esta última como un fenómeno instrumentalista, es decir, como una estrategia que usa una clase para dominar a otra (Hodder, 1982; Pearson 1982; Shanks \& Tilley, 1982; Miller \& Tilley, 1984; Kristiansen, 1984).

Los cementerios del condado de Broome participaron en una ideología dominante que produjo el avance de una clase a expensas de otras, pero el aspecto instrumental de esta ideología no explica adecuadamente toda la variación dada. Además de ser una expresión de la ideología dominante, el cementerio también participó en la lucha entre las élites rurales y urbanas de principios del siglo XIX y expresó la resistencia a la ideología dominante de una clase trabajadora étnicamente diversa del siglo XX.

No todos los cambios que vemos en el cementerio son explicables con respecto a la ideología y el poder. Muchos parecen relacionarse con cambios de una naturaleza cultural más amplia. En su nivel más básico, el cementerio es sobre la muerte, y la representación cambiante de la muerte en el cementerio no participa directamente en las relaciones de poder. Los cambios en las actitudes hacia la muerte resultan paralelos al cambio desde la naturalización a la negación observada en la ideología dominante y por lo tanto sugieren una conexión estructural subyacente más profunda.

La noción instrumental de ideología nos da una comprensión incompleta de lo que está sucediendo en los cementerios del condado de Broome. No reconoce que existen múltiples ideologías en cualquier contexto social y tiende a suponer que toda consciencia es reducible a relaciones de poder. Para obtener una comprensión más completa, primero debemos analizar el concepto teórico de ideología en términos de cultura, dominación y expresión material.

La mayoría de los investigadores están de acuerdo en qué hace la ideología. Esto es, enmascara u oculta la naturaleza real de las relaciones sociales entre los miembros de la sociedad (Althusser, 1971; Leone, 1986; 
Gramsci, 1971; Lukács, 1971; Miller \& Tilley, 1984). Esta afirmación, sin embargo, simplemente define la ideología en términos de su función, y no explica qué es la ideología.

Si tratamos de ir más allá de una definición funcional de la ideología, entonces se pueden atribuir dos significados (Larrain, 1983). El primero concibe la ideología como la totalidad de formas de la consciencia social. El segundo ve a la ideología como las ideas políticas conectadas con los intereses de una clase (Marx \& Engels, 1947). Ambos significados están incluidos en las obras principales sobre ideología y rara vez están separados (Gramsci, 1971; Althusser, 1971; Thompson, 1963; Lukás, 1971). Por ejemplo, Althusser (1971) habla de una "ideología dominante" que controla a los individuos a través de "aparatos ideológicos del Estado", y de la ideología como los aspectos dados de la vida cotidiana que forman la consciencia. Aquéllos que destacan la primera definición de ideología tienden a mantener una visión instrumentalista, como en la obra de Althusser, que ha afectado profundamente a varios arqueólogos (Leone, 1986; Handsman, 1983; Miller \& Tilley, 1984).

La definición de ideología como totalidad de la consciencia esencialmente equipara a la ideología con el concepto de cultura comúnmente sostenido en antropología, es decir, la cultura como un sistema que estructura el pensamiento o la consciencia. La cultura nos permite percibir y lidiar con el mundo porque crea orden a través de la categorización. Este proceso de categorización reduce la riqueza de la realidad a un sistema manejable, pero al hacerlo nos impide comprender la totalidad de esa riqueza. Por ejemplo, una rueda de colores es una progresión de tonos. Clasificamos esa progresión en "colores" para que podamos conceptualizar y hablar de fenómenos naturales. Los colores creados, sin embargo, nos niegan una subdivisión diferente de la totalidad que produciría diferentes colores. Desde esta perspectiva, el proceso de percibir el mundo es necesariamente mistificante ya que nos permite cierto conocimiento del mundo pero sólo al negarnos otro.

La cultura no es una estructura cognitiva a priori ni es perfecta. Más bien, es creada a través de procesos históricos y contiene contradicciones internas. No puede tener una existencia superorgánica; debe residir en las mentes de los individuos. Paradójicamente, la cultura no se origina ni cambia en las mentes de los individuos porque sea un fenómeno social. La cultura es creada y recreada constantemente a través de las interacciones de los individuos con otros individuos, grupos sociales y las condiciones materiales de la vida. Los individuos participan diferencialmente en estas interacciones y con diversos intereses, de modo que la cultura es un sistema muy imperfecto, compartido de forma diferencial por los individuos y propenso a inconsistencias y contradicciones.

Es importante considerar a la cultura como algo mayor que la ideología, y reconocer que la relación entre estos fenómenos es creada históricamente. La mistificación inherente a la percepción no se limita a las relaciones de poder. Las relaciones de poder, sin embargo, deben engendrar siempre tal mistificación ya sea consciente o inconscientemente. La ideología, por lo tanto, es esa parte de la cultura que se origina a partir de la relación entre la consciencia y el poder. Esta relación no se da en todos los tiempos y lugares, por lo que los aspectos específicos de la cultura (creencias, rituales, suposiciones básicas, etc.) pueden estar cargados ideológicamente en un contexto y no en otro. Como muestra el estudio de Maurice Bloch (1986) sobre el ritual de la circuncisión de Merina en Madagascar, las formas, expresión y contenido de aspectos específicos de la cultura pueden mantenerse increíblemente constantes incluso cuando la relación entre consciencia y poder, y las consecuencias ideológicas de esta relación, pueden estar cambiando radicalmente a lo largo del tiempo 
Ubicar a la ideología dentro de una estructura de cognición cultural más amplia elimina la interpretación más simplista de la posición instrumentalista. Esta interpretación podría fortalecer las ideas de la clase dominante para determinar toda la consciencia social. Pocos defensores de la ideología instrumentalista tomarían esta posición extrema, pero todos verían las ideas de la clase dominante como determinantes de la relación entre consciencia y poder, y como una herramienta sólida para controlar a los grupos subordinados.

Abercombie, Hill \& Turner (1980) han publicado una crítica de lo que definen como la "tesis dominante de la ideología”. Desafían tanto la naturaleza instrumental como la efectividad de la ideología para influir en la acción social. Argumentan que en la mayoría de los períodos históricos la ideología dominante sirvió principalmente para integrar a la clase dominante y a las clases subordinadas rechazadas. Concluyen que la ideología dominante es un instrumento débil porque estas ideologías están fracturadas y a menudo son contradictorias. Su crítica sugiere que la ideología genera tanto resistencia como dominación y que la ideología debe estar incluida en una consciencia cultural mayor.

A lo sumo, argumentos como los de Abercombie, Hill \& Turner (1980) sugieren que las discusiones de ideología sólo se refieren a las acciones de una élite y nos dicen poco sobre cómo se crean y mantienen las desigualdades. Eliminar totalmente la ideología de nuestros discursos sobre el poder ignora que la ideología está incluida en la cultura. Incluso en los ejemplos dados por Abercombie, Hill \& Turner (1980) parece que las clases subordinadas no rechazan la ideología dominante sino que la reelaboran para sus propios fines y que las ideologías de resistencia comparten mucho con las ideologías dominantes. La ideología como aquella parte de la cultura que se origina en la relación entre consciencia y poder participa en la negociación de las relaciones sociales, pero no de la manera simple que es planteada en la noción instrumentalista.

Como se la define aquí, la ideología puede tener múltiples funciones en la negociación de las relaciones sociales. Una ideología es tanto el producto como un prerrequisito para que un grupo alcance una consciencia política y, como tal, siempre sirve para integrar alguna clase o parte de una clase en las luchas de poder. Para mantener el dominio, una clase dominante debe estar integrada por una ideología y debe mistificar el poder de la clase representando sus intereses como los intereses comunes de toda la sociedad (Marx \& Engels, 1946; Larrain, 1983). Esta ideología puede ser aceptada por las clases subordinadas o pueden convertirla en ideología de la resistencia. El conflicto puede ser el resultado de las inconsistencias entre la ideología de las élites y la ideología de los subordinados, lo que proporciona la base consciente para la resistencia. El cambio en el ideal mueve a las personas a la acción, y esta acción transforma la realidad, nuevamente desafiando al ideal (Godelier, 1982). Por lo tanto, las ideologías subordinadas pueden revelar relaciones de poder pero, como son culturales, también mistifican la realidad. Dicha mistificación sólo sirve para reproducir y legitimar las desigualdades en la sociedad si el grupo subordinado llega a dominar.

Las ideologías dominantes pueden mistificar la verdadera naturaleza de las relaciones sociales en al menos dos maneras fundamentalmente diferentes. Pueden negar la existencia de la desigualdad o pueden naturalizar la desigualdad. La ideología niega la existencia de la desigualdad enmascarando u ocultándola. La ideología naturaliza las desigualdades no al negar su existencia sino al negar que son productos sociales. En este último caso, las fuentes de la desigualdad son atribuidas a factores no sociales como lo sobrenatural, las características de la personalidad de los individuos, las hormonas o los genes.

La ideología no existe sólo en la mente de las personas, sino que tiene manifestaciones materiales y de comportamiento observables; surge de la opacidad de la realidad (Mepham, 1979). Las agrupaciones sociales, el comportamiento y los objetos materiales encarnan la ideología y le otorgan realismo. Las apariencias 
creadas por estas cosas satisfacen las expectativas de la ideología, y a través de esta afirmación recrean y legitiman la ideología. Por ejemplo, el estilo y tamaño uniforme de las lápidas en los cementerios del condado de Broome a principios del siglo XIX legitimaron y afirmaron una ideología igualitaria que negaba las desigualdades en la comunidad. Los individuos perciben la realidad de manera diferenciada, dependiendo de su propia experiencia, de modo que la realidad no es igual para todos los miembros de la sociedad. Las relaciones sociales canalizan esta experiencia, y esas diferencias son una precondición para las ideologías múltiples.

Los distintos tipos de mistificación resultan y requieren de la manipulación de los objetos materiales de maneras diferentes. Si se niegan las desigualdades, entonces se debe restar importancia a la evidencia material de esa desigualdad. Cualquier exhibición material pública y visible de desigualdad revelaría que la ideología es una mistificación. Por el contrario, la naturalización no sólo puede implicar la expresión material de las desigualdades, sino también incluso el incremento de las desigualdades. La realidad de las diferencias materiales sirve para objetivar y validar el supuesto origen natural de esas desigualdades.

La mistificación no resulta de elementos individuales o creencias, sino de un sistema de elementos (Mepham, 1979). El ritual del entierro no se mistifica en sí y por sí mismo. Se mistifica porque es parte de una estructura más grande de creencias y símbolos materiales. Esta estructura cultural incluye otros aspectos de la ideología y aspectos de la consciencia que no están involucrados en las relaciones de poder. El ritual del entierro debe mantener una consistencia mínima con otros rituales y símbolos materiales, y reforzar su mensaje. El papel del ritual mortuorio en la mistificación no es comprensible sin hacer referencia a este sistema de significado mayor.

$\mathrm{Al}$ estudiar una ideología, debemos tratar de comprender los principios subyacentes que la estructuran, las divergencias y contradicciones dentro de ella y la dialéctica a través de la cual es creada y recreada (Marx, 1978). Tal comprensión sólo puede lograrse en el contexto de un caso histórico específico. El diálogo que los muertos del condado de Broome mantuvieron con los vivos es un discurso ideológico. Este discurso reunió aspectos aparentemente divergentes de la cultura e ideología relacionados con la muerte, la familia y el estatus social. Examinando estos aspectos, podemos descubrir cambios estructurales en la ideología y la cultura subyacentes.

\section{El CONDADO DE BROOME}

El condado de Broome se encuentra en el centro-sur del estado de Nueva York, a lo largo de la frontera con Pensilvania. En la actualidad el condado tiene tres ciudades principales, la ciudad de Binghamton y los pueblos de Johnson City y Endicott, y posee una población total de alrededor de un cuarto de millón de habitantes. El área fue y es un centro de manufacturas con variedad de grupos étnicos y clases sociales. Han sobrevivido suficientes cementerios como para darnos una muestra para estudiar las lápidas que representan más de 150 años de cambios. El área no es tan grande como para que no podamos examinarla por completo, pero contiene suficiente variabilidad social e histórica como para permitir estudiar la ideología en los cementerios.

Los protestantes blancos anglosajones de Nueva Inglaterra y Pensilvania se asentaron inicialmente en el condado a fines de 1700 y principios de 1800. La economía de la región se mantuvo rural hasta mediados del siglo XIX, cuando el condado de Broome comenzó a desarrollarse como un centro de manufactura. La 
industria del cigarro dominó el condado durante la última parte del siglo XIX. La fabricación de calzado reemplazó gradualmente a los cigarros a fines del siglo XIX, y en la década de 1920 una compañía de zapatos, Endicott Johnson Shoe Company (EJ), empleó al 60 por ciento de la fuerza laboral industrial en el condado. En el período posterior a la Segunda Guerra Mundial, EJ fue reemplazado por IBM como el principal empleador en el condado.

Las fábricas de cigarros y EJ activamente alentaron el trabajo de inmigrantes, al traer más de 12 grupos étnicos diferentes a la comunidad. Los irlandeses fueron los primeros en arribar. Llegaron como trabajadores de la construcción en la década de 1830 y hasta finales del siglo XIX proporcionaron la mayor parte de la mano de obra para las fábricas de cigarros. A fines del siglo XIX, los irlandeses se unieron rápidamente a la clase media como abogados, comerciantes y empleados públicos.

La industria del calzado que le procedió se basó en el trabajo de la segunda gran ola de inmigrantes, principalmente italianos y europeos del Este, y una inmigración a gran escala de "estadounidenses nativos" de las zonas rurales del oeste de Pensilvania. Los italianos que se dedicaban a la construcción vivían en Binghamton y los zapateros italianos vivían en Endicott. Los europeos del Este provenían de diferentes grupos étnicos y practicaban diferentes religiones, manteniéndolas en el condado de Broome. El grupo más grande de europeos del Este fueron los eslovacos, entre los que había tanto católicos como luteranos. Muchos de los europeos del Este eran judíos y se concentraron en el centro de Binghamton. Los judíos no trabajaban en las fábricas de calzado, sino en la industria de la indumentaria de Binghamton y se convirtieron en propietarios de pequeños negocios.

Esta inmigración alcanzó su punto máximo en el período comprendido entre 1919 y 1922, antes de que las leyes federales de inmigración la limitaran. Desde entonces ha habido un cierto desplazamiento de asiáticos hacia Binghamton y una constante serie de migraciones, pero en declive, de individuos pertenecientes a los grupos de la segunda gran ola. Los hijos y nietos de los inmigrantes extranjeros y rurales de principios del siglo XX continúan constituyendo la mayor parte de la clase trabajadora del condado de Broome, con la excepción de los judíos, quienes en gran medida tienen empleos en ámbitos profesionales, educativos y administrativos. A partir de la década de 1940, algunos de los europeos del Este alcanzaron un estatus de clase media a través del comercio, y algunos italianos se establecieron con éxito como contratistas.

\section{DATOS Y MÉTODOS}

Los datos presentados en mi discusión se derivan de un proyecto mayor, el Proyecto de Lápidas de Binghamton, en curso desde el otoño de 1982. La tumba más temprana que hemos encontrado en el condado de Broome data de la década de 1790. Dos de los primeros cementerios del condado fueron destruidos en el siglo XIX. Uno fue erosionado por el río Susquehanna y el segundo fue destruido para construir las vías del ferrocarril. En general, tenemos datos adecuados en nuestra muestra desde mediados del siglo XIX hasta 1980.

Al recolectar los datos para el proyecto, hemos intentado construir una muestra representativa para todo el condado. Este es un trabajo inmenso porque estimamos que hay al menos varios cientos de miles de lápidas en el condado. Hasta el momento, hemos recopilado datos sobre más de 2.000 lápidas en más de 27 cementerios. Esta muestra incluye cementerios familiares y públicos en las zonas rurales, 5 cementerios 
protestantes urbanos, 3 cementerios católicos (incluyendo irlandeses, italianos y eslovacos) y 3 cementerios judíos.

Además de recolectar datos de las lápidas, hemos examinado y documentado todos los mausoleos familiares en el área metropolitana (Roveland, 1984). Este estudio nos proporciona información descriptiva de cada mausoleo y datos bibliográficos sobre las personas que los construyeron.

La información recolectada en las lápidas del cementerio representa sólo la mitad de los datos disponibles para nosotros. Hemos utilizado guías telefónicas de ciudades, censos manuscritos, obituarios, otros documentos e informantes para identificar a los individuos enterrados bajo nuestras lápidas. Para aproximadamente dos tercios de las lápidas de nuestra muestra, sabemos la etnicidad del individuo, la ocupación inmediatamente antes de la muerte o jubilación, el lugar de residencia al momento de la muerte y la relación con otros individuos enterrados en las cercanías. Esta información nos permite examinar el vínculo entre el estatus social de los individuos y cómo estaban marcadas sus tumbas.

Registramos una amplia variedad de datos para cada lápida. Copiamos toda la información escrita exactamente como se presenta en las lápidas. Registramos una gran cantidad de otras variables, incluyendo materia prima, tamaño, fecha estimada en que se erigió y tipo formal de lápida, el tipo de parcela en que se encuentra y, por supuesto, el cementerio. En total, registramos más de 50 observaciones para cada lápida.

Los proyectos de investigación de lápidas a menudo se inician sin un abordaje explícito y riguroso para la selección de las lápidas a analizar. Esto es desafortunado ya que el investigador es atraído hacia lo inusual y monumental en el cementerio. Una gran cantidad de sesgos no declarados e inconscientes entran en la selección de la muestra. Para evitar este problema, ideamos un enfoque estructurado para seleccionar las lápidas para nuestro análisis. En los cementerios para los cuales teníamos mapas que mostraban las parcelas, primero estratificamos el cementerio según las subdivisiones administrativas dentro del cementerio y luego seleccionamos parcelas para examinarlas mediante el uso de una tabla de números aleatorios. Para la mayoría de los cementerios, sin embargo, tales mapas no existían o no tuvimos acceso a ellos. En estos casos, primero subdividimos el cementerio en unidades más pequeñas y luego seleccionamos lápidas al azar dentro de estas unidades más pequeñas. En todos los casos, nuestra unidad de muestreo fue el grupo. Luego de seleccionar una lápida, registramos todas las otras lápidas de ese mismo grupo. Aunque no deseamos argumentar que estos procedimientos nos brindan una muestra completamente representativa, nos permiten examinar una amplia variabilidad en los cementerios y hacer explícitos los sesgos en nuestra selección de datos.

\section{El Cambio de Aspecto de los Cementerio Del Condado de Broome}

Los cambios que vemos en los cementerios del condado de Broome generalmente siguen las mismas tendencias que Dethlefsen (1977) ha proyectado para todo Estados Unidos. El condado de Broome nunca fue uno de los centros de innovación cultural de este país, por lo que tiende a haber un ligero retraso en la adopción de nuevas formas conmemorativas y cementerios en comparación con otras áreas. Este retraso disminuyó con el tiempo, aunque incluso hoy juzgaría que las costumbres de marcar tumbas en el condado son conservadoras.

Los cementerios del condado de Broome de fines del siglo XVIII y principios del siglo XIX diferían poco de sus homólogos de Nueva Inglaterra (Tashjian \& Tashjian, 1974; Benes, 1977; Deetz \& Dechlefsen, 1978). Durante la primera mitad del siglo XIX, los cementerios eran comunitarios, propiedad de iglesias o pueblos. 
Los individuos tuvieron acceso al cementerio a través de su pertenencia a la ciudad o iglesia. Las tumbas seguían siendo propiedad de la comunidad y no se transfería ni al individuo ni a la familia. La comunidad les concedía a las familias derechos de uso en el cementerio, y las tumbas se organizaban en grupos familiares. Inicialmente, parece haber habido poco ordenamiento sistemático en las tumbas, pero en la segunda década del siglo XIX tendieron a colocarse en hileras prolijamente ordenadas.

Las lápidas más antiguas fueron elaboradas con esquisto oscuro, disponible en el norte del estado de Nueva York y se modelaron para parecerse a la cabecera de una cama (Figura 1). Hasta la década de 1820, estas lápidas fueron decoradas principalmente con motivos de urnas y sauces aunque con algunas variaciones. Las lápidas comúnmente contenían epitafios que hablaban de las recompensas que se esperaban en el cielo y de escapar del sufrimiento de esta vida.

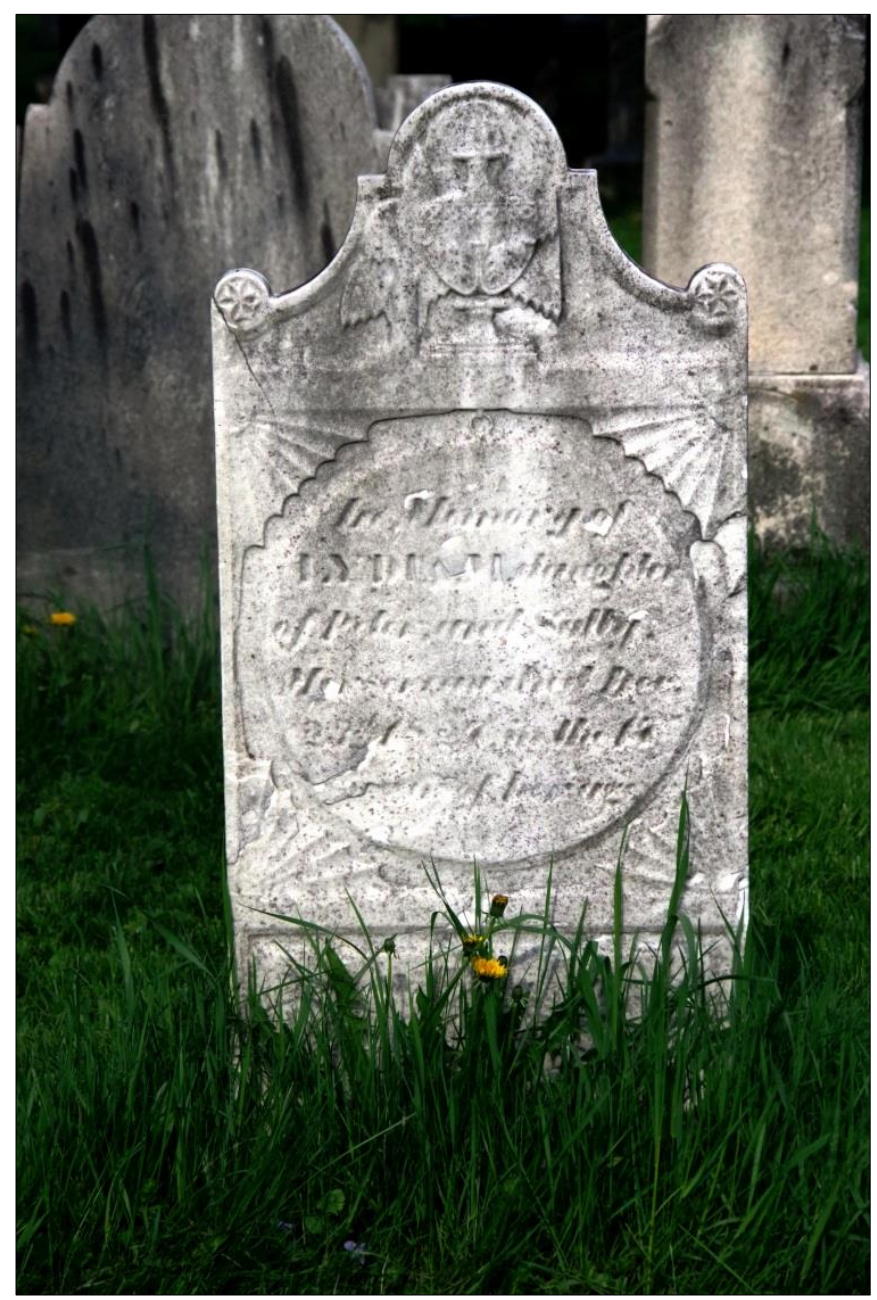

Figura 1: Lápidas como cabecera de una cama con motivos de urnas y sauces.

El uso de diseños de urnas y sauces y de este tipo de epitafios continuó hasta principios del 1800, pero en las primeras décadas cambió la forma y la materia prima de las lápidas. El mármol reemplazó al esquisto y las lápidas rectangulares desplazaron a la forma de cabecera de una cama. El mármol ingresó al condado de Broome en grandes placas, que los artesanos locales cortaban en lápidas y en las que tallaban diseños y epitafios (Gibb, 1985). En el cementerio, las resplandecientes lápidas blancas marcaban las tumbas de los 
miembros de la familia dispuestas en una hilera (Figura 2). Las variaciones en el tamaño usualmente reflejaban las diferencias entre niños y adultos, pero es muy poco evidente la desigualdad general en cuanto al tamaño y la complejidad de las lápidas (Figura 3).

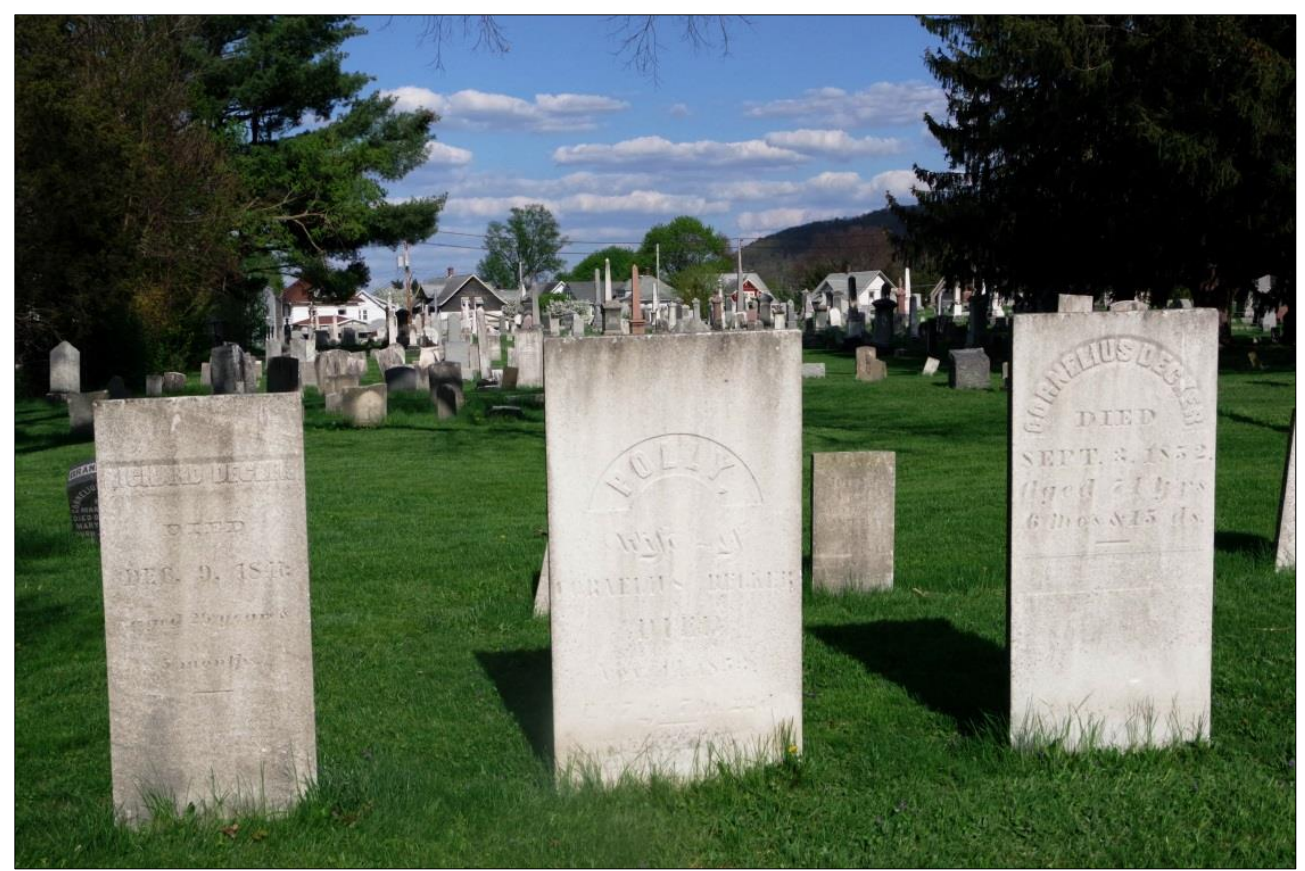

Figura 2: Grupo familiar con marcadores de lápida de principios del siglo XIX.

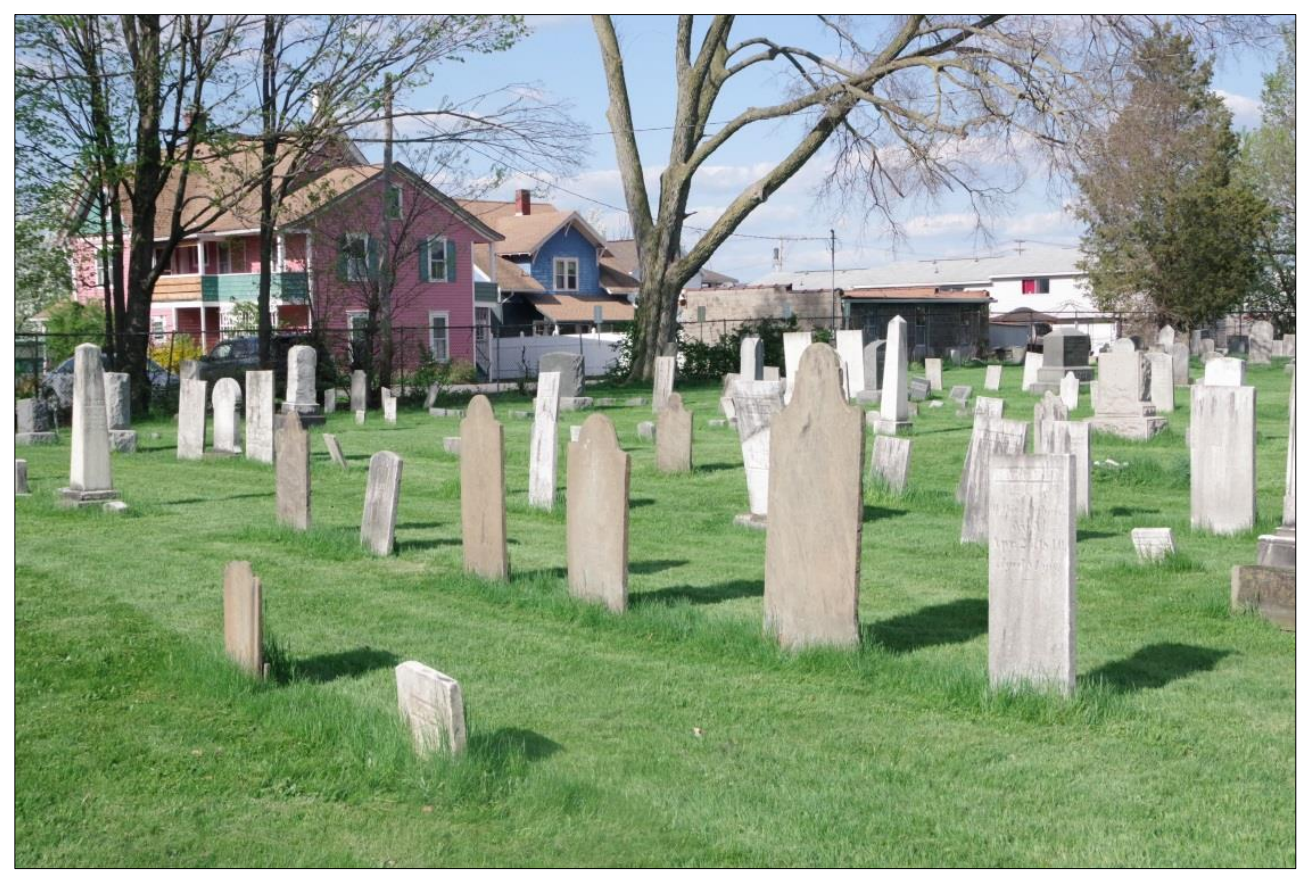

Figura 3: Un cementerio de iglesia de principios del siglo XIX.

A partir de la tercera década del siglo XIX, la forma del cementerio estadounidense comenzó a tomar una nueva configuración. En Boston, el comienzo del movimiento del cementerio jardín marcó la aparición de este cambio. El movimiento del cementerio jardín fue una reacción y un rechazo explícito al antiguo 
cementerio comunitario (French, 1975; Farrell, 1980; Darnall, 1983). Los defensores del movimiento consideraron a los cementerios anteriores como sucios, insalubres y poco atractivos. Sostuvieron que debía encontrarse una forma más sanitaria y atractiva de disponer a los muertos. Ellos buscaron reubicar al cementerio en áreas rurales retiradas de las viviendas, en entornos parecidos a un parque en donde la gente pudiera realizar picnics, caminar, contemplar y absorber las lecciones morales entretejidas en el paisaje del cementerio (French, 1975).

Para lograr este objetivo, formaron asociaciones que establecieron y administraron los cementerios. Los individuos se hacían miembros de la asociación al comprar parcelas en el cementerio. Inicialmente, los partidarios del movimiento se opusieron a cercar las parcelas y a construir monumentos llamativos. Estas objeciones se desvanecieron pronto cuando las familias convirtieron sus parcelas en declaraciones elaboradas sobre su riqueza y poder.

En la década de 1860 apareció un nuevo tipo de cementerio, el cementerio parque. Incorporó muchas de las características del cementerio jardín como la propiedad privada de parcelas y monumentos llamativos. Estos cementerios se diferenciaron al no intentar mantener el paisaje natural. Por el contrario, enfatizaron la dominación humana sobre el paisaje modificándolo cuidadosamente para formar un parque. Estos cementerios tendieron a estar muy orientados comercialmente y muchos fueron empresas con fines de lucro (Farrell, 1980).

En 1854, los principales ciudadanos del condado de Broome organizaron el primer cementerio jardín, Spring Forest, en el extremo oeste de Binghamton. Éste fue seguido en esa misma década por un cementerio protestante de clase baja y un cementerio católico, ambos modelados según los cementerios jardín. El siguiente gran cementerio de clase alta, Floral Park, fue organizado como un cementerio parque en 1893. Todos los cementerios posteriores que se establecieron en el condado, incluidos los creados por grupos religiosos, se organizaron como asociaciones, y en 1900 casi todos los cementerios comunitarios fueron reorganizados como asociaciones, abandonados, rellenados o destruidos por la expansión urbana. El concepto de cementerio parque siguió siendo el modelo básico para los nuevos cementerios en el condado de Broome hasta la década de 1930.

La introducción de los nuevos estilos de lápidas acompañó el establecimiento de los cementerios jardín y transformó la apariencia de los cementerios ya existentes. Desde 1850 hasta el cambio de siglo, el tamaño y la variedad de las lápidas aumentaron a medida que las familias invertían cada vez más en marcadores de tumbas (Figura 4). Además de lápidas, también se erigieron marcadores familiares más grandes. La forma más tempranas de estos marcadores fueron los obeliscos, pero la variedad en las diferentes formas se incrementó hasta la década de 1880 cuando se observaron decenas de formas diferentes (Figura 5). Para 1870, las materias primas utilizadas para la elaboración de los monumentos conmemorativos pasaron de ser predominantemente de mármol a predominantemente de granito. 


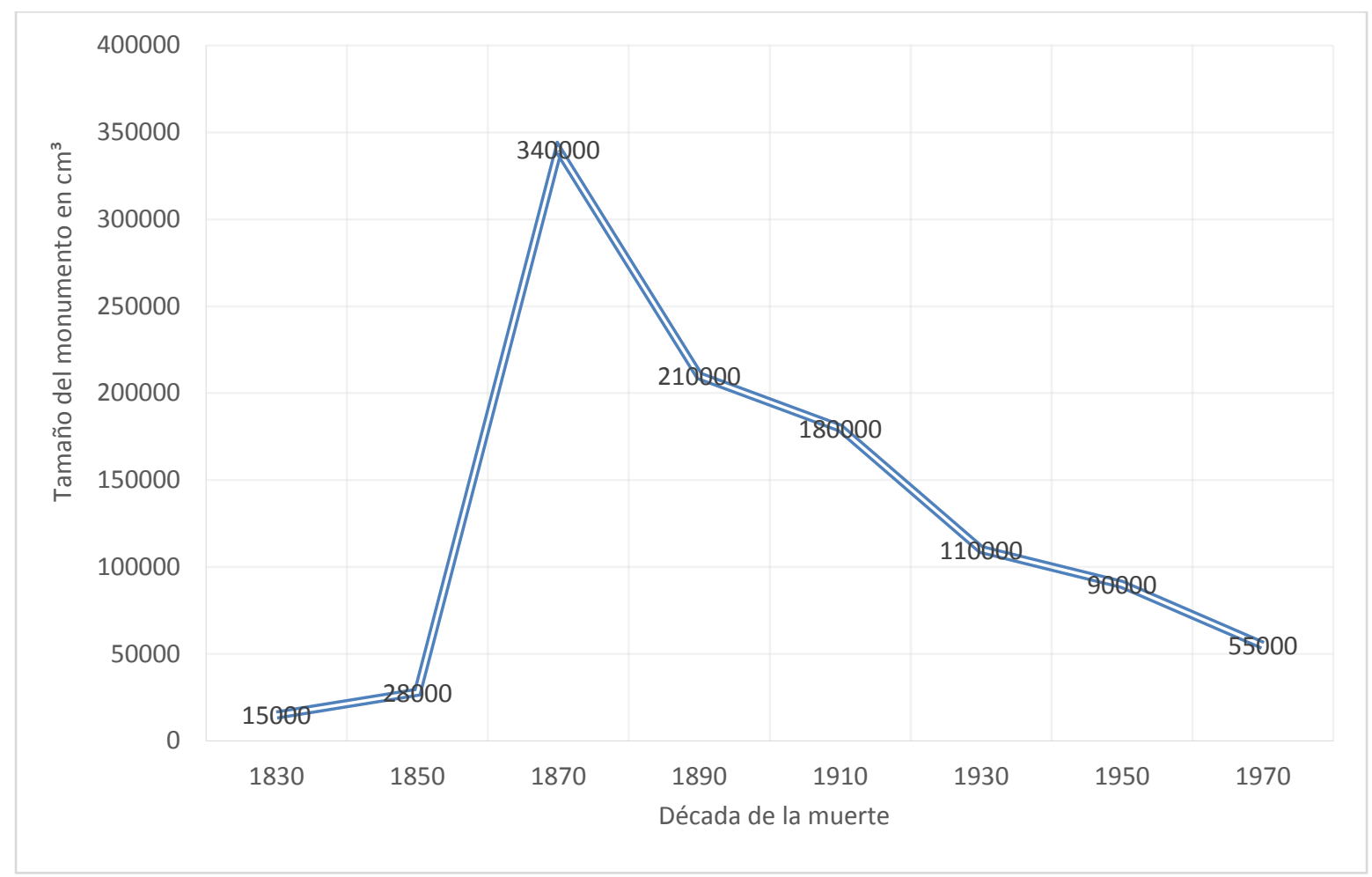

Figura 4: Gráfico mostrando los cambios generales en la inversión mortuoria.

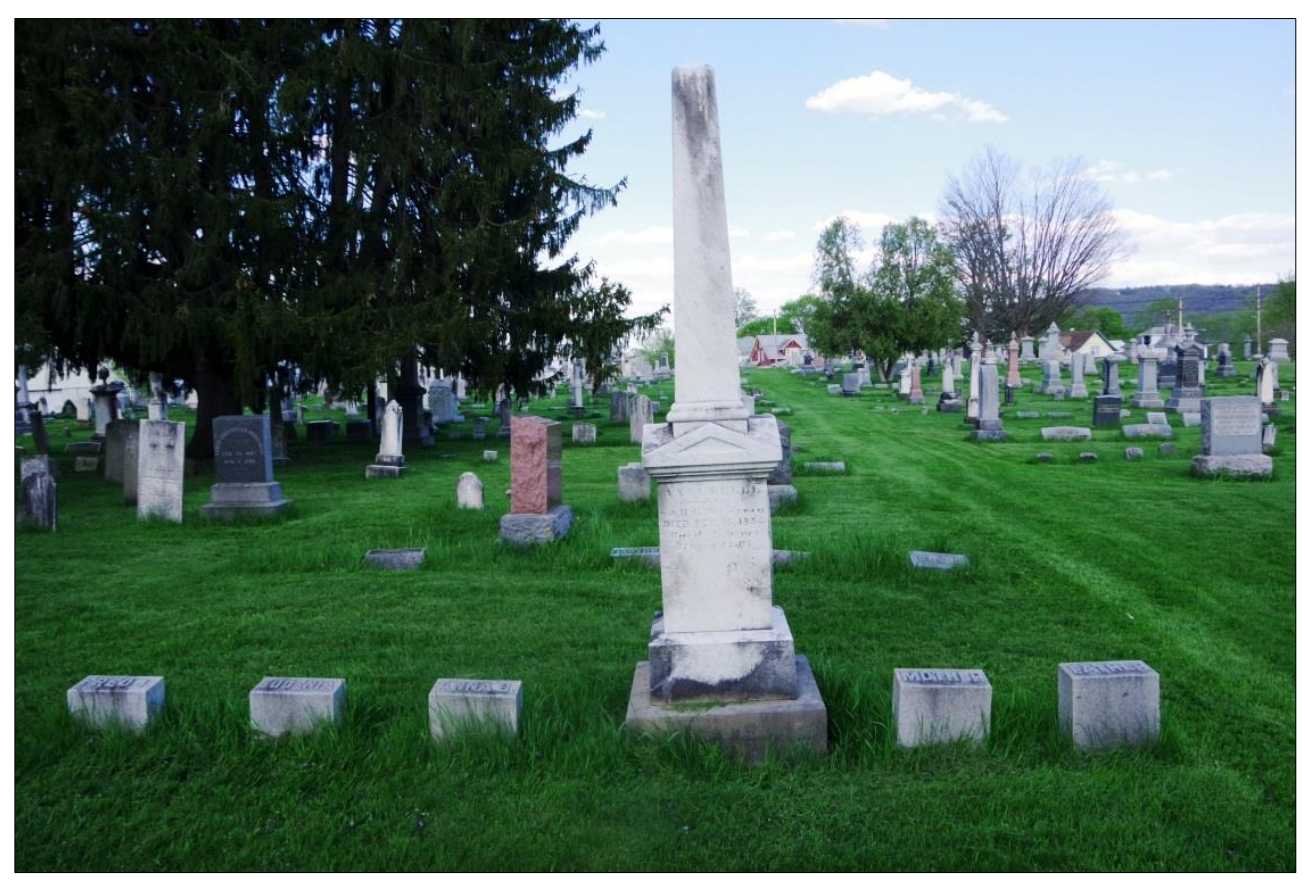

Figura 5: Una parcela familiar con un obelisco de mediados del siglo XIX.

Con la introducción de los marcadores familiares, la familia también se reorganizó en el cementerio. La familia dejó de descansar en la muerte unos al lado de los otros en una línea recta. Un destacado gran marcador, a menudo referido como marcador familiar, fue erigido en el centro de la parcela familiar. Sin embargo, este monumento fue menos para conmemorar a la familia que un monumento a su patriarca, el esposo. Estos marcadores centrados en el esposo muestran en forma destacada el nombre completo del 
mismo (Figura 6). Todos los nombres de los otros miembros de la familia están dados por su relación con el esposo (por ejemplo, Sarah, esposa de John Smith, o David, hijo de John Smith). En unos pocos casos en los que la esposa pertenecía a una familia más prominente que la del marido, ella aparecía con su apellido de soltera. Una lápida suele marcar cada tumba individual en la parcela con la posición generacional y de género de cada persona de la familia (padre, madre, hija, abuelo, etc.), identificando al miembro de la familia.

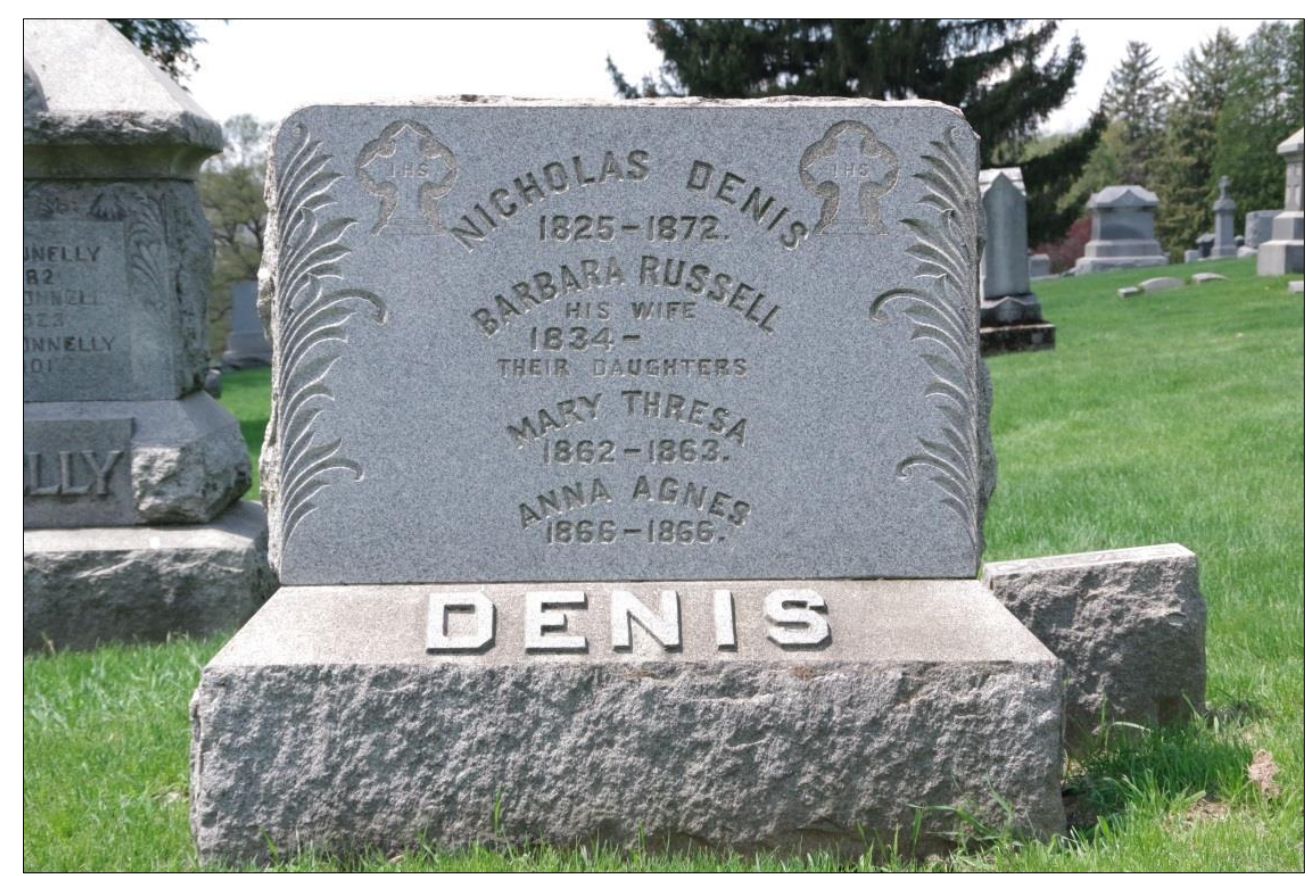

Figura 6: Una parcela familiar centrada en el marido de finales del siglo XIX.

En la actualidad, las parcelas más grandes y prominentes de estas familias aún tienen paredes bajas de granito a su alrededor que las separan claramente de otras en el cementerio. Los observadores contemporáneos habrían visto una mayor segregación de familias, ya que muchas parcelas originalmente estaban rodeadas por rejas de metal con puertas. Casi todas las rejas se han oxidado o fueron removidas en tiempos posteriores para facilitar el mantenimiento de los terrenos del cementerio.

El tipo de parcela más prominente y costoso para la familia fue el mausoleo familiar (Figura 7). En el condado de Broome hay 62 estructuras de este tipo, y podríamos fechar y reconstruir la posición social de las familias que construyeron 47 de ellas. Los primeros mausoleos familiares aparecieron en la década de 1880 y la construcción de estos monumentos alcanzó su punto máximo en el primer tercio del siglo XX. Entre 1900 y 1910 se construyeron 14, y 20 más en las siguientes dos décadas (Roveland, 1984). Empresarios, fabricantes, banqueros y profesionales protestantes erigieron 18 de los 22 mausoleos familiares construidos antes de 1920. Los 3 restantes fueron construidos por viajantes de comercio y un empresario irlandés. 


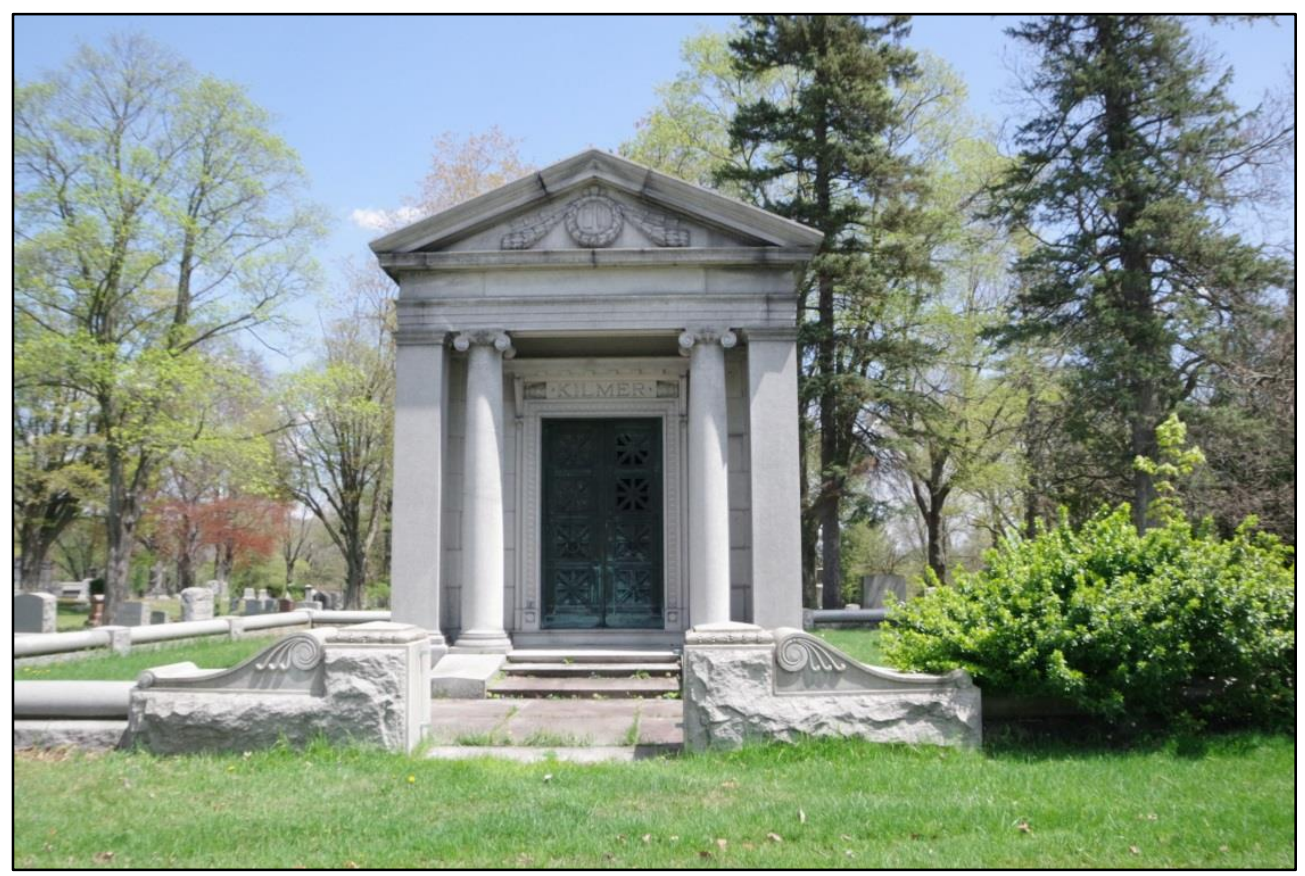

Figura 7: Mausoleos de finales del siglo XIX.

Las parcelas familiares de cada cementerio competían entre sí para llamar la atención del visitante. El marcador central fue el foco de atención de la parcela, atrayendo la mirada a través de una combinación de tamaño y singularidad. No todos los marcadores fueron (y son) exitosos en esta competencia. Los mausoleos y las lápidas realmente monumentales de los capitalistas locales capturan primero al observador y atraen incluso a aquéllos que no ingresan al cementerio (Figura 8). Los marcadores de la clase media irlandesa y protestante alientan al visitante a recorrer el cementerio de lápida en lápida para examinar las diferencias en cuanto a forma y detalle, y reflexionar sobre la familia que erigió el monumento (Figura 9). 


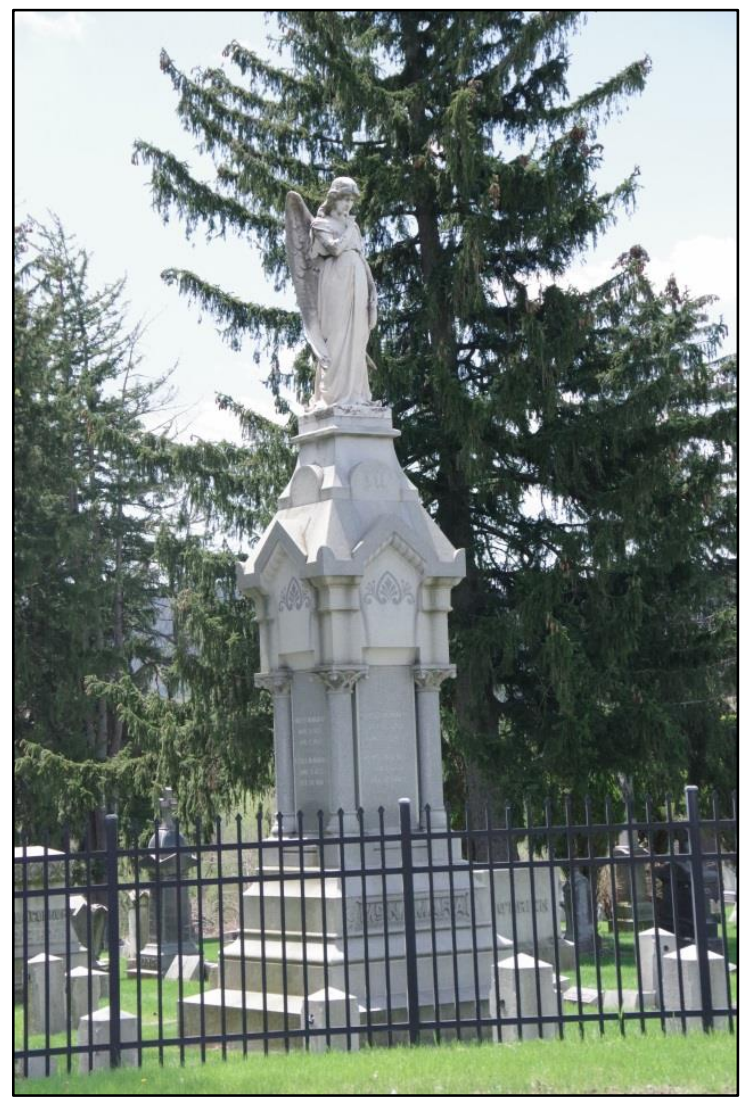

Figura 8: Monumento de una familia adinerada de fines del siglo XIX.

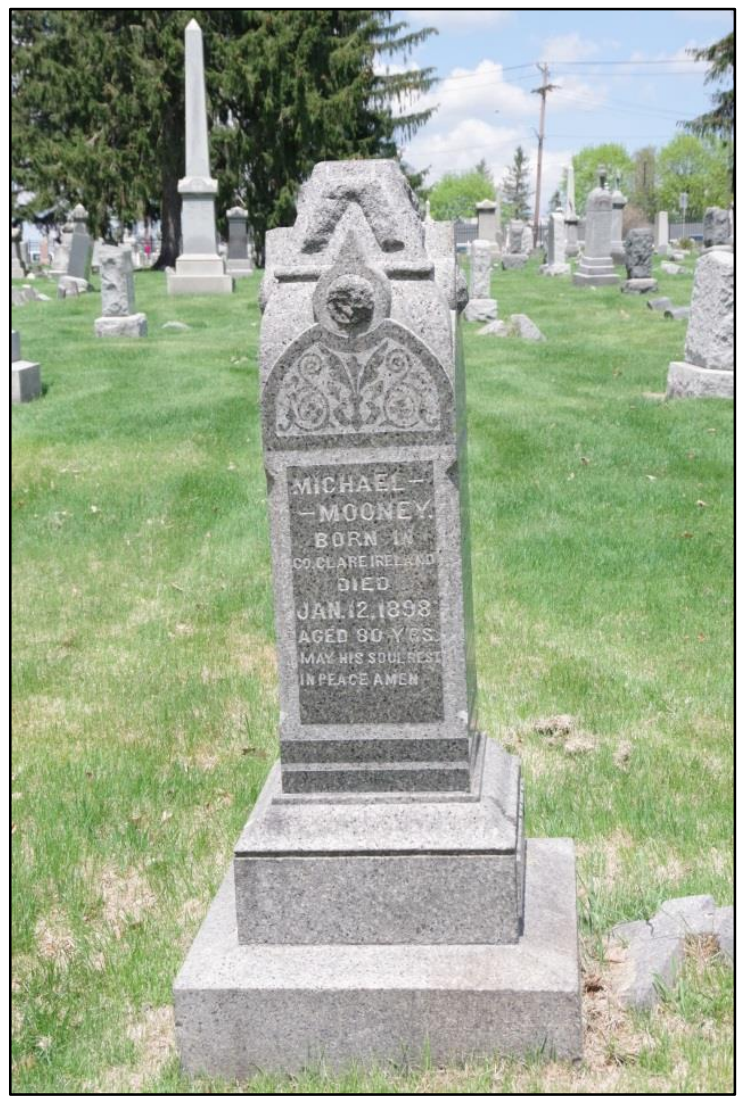

Figura 9: Monumento de clase media de finales del siglo XIX. 
Las parcelas familiares de fines del siglo XIX y principios del siglo XX también aprovecharon la localización tanto dentro como entre los cementerios para competir por la atención. En los cementerios del condado de Broome de este período, existió una jerarquía de prestigio definida entre los cementerios protestantes, que cambiaron con el tiempo. Dentro de cada cementerio, incluido el católico, los mausoleos y los más grandes monumentos tienden a agruparse en el terreno más alto, con los monumentos menores diseminados a su alrededor.

El observador moderno ocasional de este paisaje, sin embargo, suele pasar por alto las numerosas tumbas de los trabajadores que se encuentran en los cementerios de menor prestigio y las que bordean los límites de los cementerios católicos de mayor prestigio. Estas tumbas están señalizadas con lápidas simples, generalmente de mármol, ahora grises por la erosión y la contaminación. Aún menos visibles para el observador moderno son las numerosas tumbas sin marcar en los cementerios protestantes de menor prestigio y a lo largo de los bordes de los cementerios católicos. En la actualidad, estas tumbas son sólo visibles como pequeñas depresiones en el suelo. El visitante contemporáneo de estos cementerios habría tenido una mejor visión de estas tumbas menores porque el mármol habría sido brillantemente blanco y habría estado menos cubierto por la vegetación. Asimismo, la actual extensión vacía de tumbas sin señalizar habría sido esporádicamente marcada por la tierra desnuda que cubre las adiciones más recientes del osario o sector de fosa común.

Desde mediados del siglo XIX hasta las dos primeras décadas del siglo XX, el cementerio del condado de Broome claramente reflejó el estatus y posición social de las personas que fueron enterradas en él. Las suposiciones arqueológicas concernientes a una relación directa entre inversión mortuoria y riqueza o poder son válidas por el momento. El cementerio enfrenta al observador con marcadas desigualdades en inversión y exposición (Figura 10).

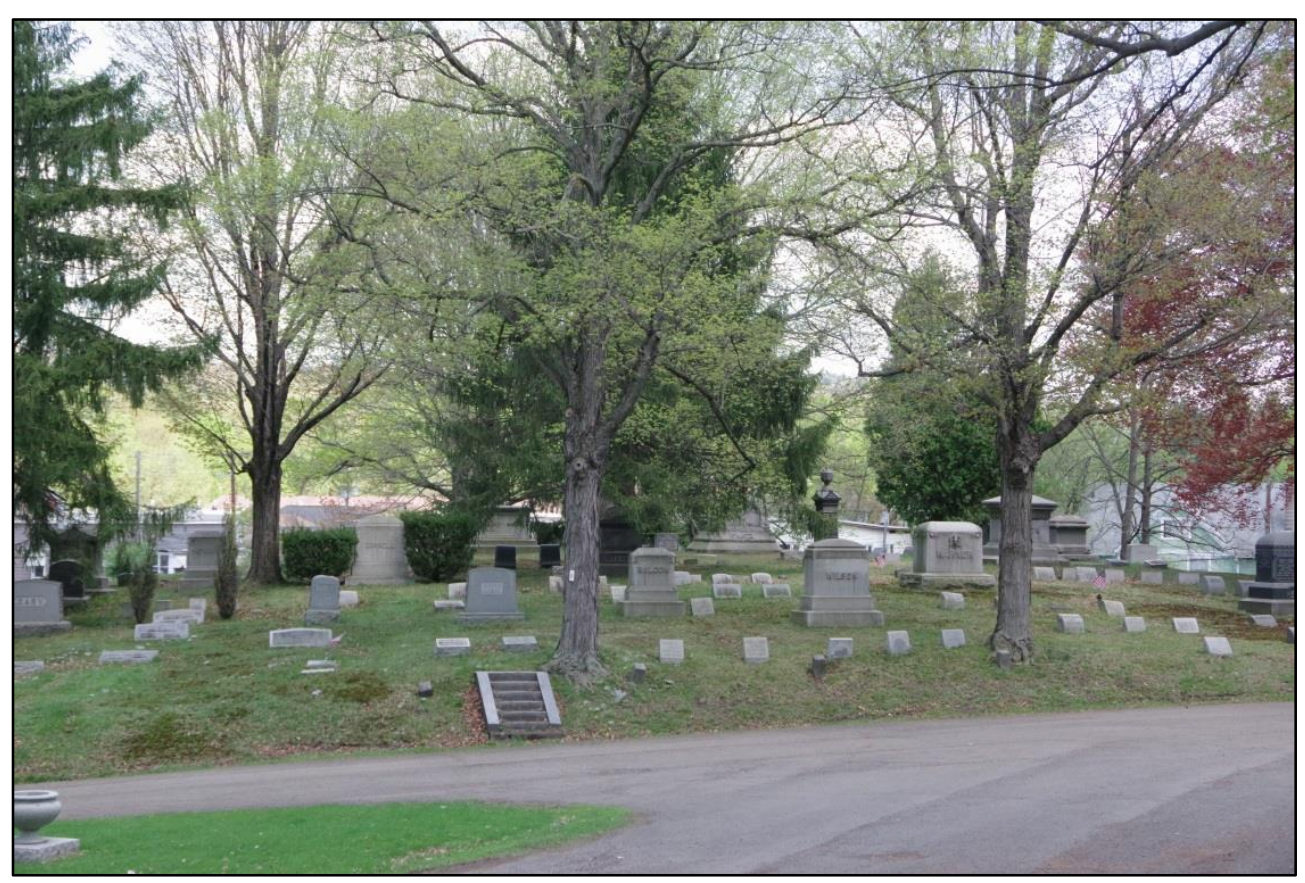

Figura 10: Un cementerio parque. 
Existen indicios de cambio en este patrón durante la segunda década del siglo XX, a medida que comienza a disminuir la inversión general en lápidas y mausoleos. En el período entre las guerras mundiales, parece haber habido una renegociación del diálogo en el cementerio. Tanto la inversión en exhibiciones mortuorias como la variedad de dichas exhibiciones disminuyeron. También ocurrieron alteraciones significativas en la distribución de formas e inversiones dentro de la comunidad.

Las parcelas familiares continuaron siendo la forma más común de agrupamiento en el cementerio durante el período de entreguerras. Sin embargo, los marcadores familiares se volvieron menos variados y más uniformes en tamaño. También se convirtieron, de hecho, en verdaderos monumentos de la familia, mostrando sólo el apellido de la misma. Los nombres de los individuos aparecen en las lápidas con designaciones como padre, madre o hija (Figura 11). Las relaciones familiares, que antes se habían mostrado secundarias al patriarca masculino, asumen primacía en el diálogo que el difunto desea instigar.

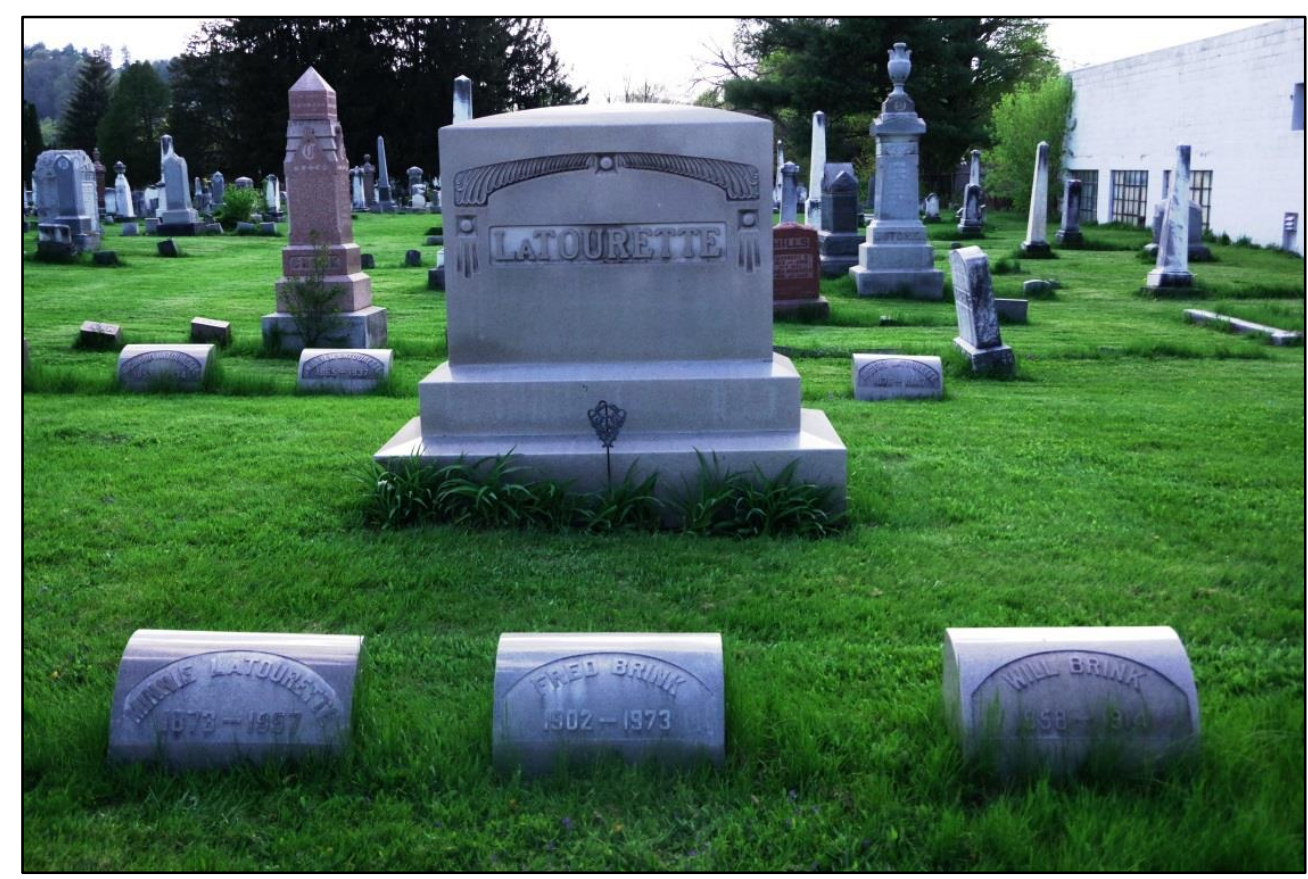

Figura 11: Una parcela familiar de la década de 1920.

La relación directa que se vio antes entre la inversión mortuoria y la posición social se volvió confusa en los años 1920 y 1930. Muchas familias irlandesas y protestantes adineradas y prominentes continuaron construyendo mausoleos y tres familias irlandesas prominentes erigieron construcciones monumentales (dos obeliscos y una gran cruz celta). Algunas familias prominentes, sin embargo, comenzaron a erigir monumentos conmemorativos mucho más modestos. Los italianos y los eslovacos, a pesar de su bajo estatus social y riqueza, comenzaron a erigir monumentos conmemorativos importantes en los años 1920 y 1930. Las familias italianas encargaron varios sarcófagos, una forma de conmemoración por encima del suelo cuyo costo estaba en segundo lugar después de los mausoleos. En 1938, un propietario eslovaco de una licorería construyó un mausoleo con un costo de $\$ 8.000$. En ese momento, una casa nueva y grande de tres habitaciones se vendía en el condado por $\$ 4.000$.

La impresión general del cementerio cambió mucho en el período de entreguerras (Figura 12). Importantes construcciones conmemorativas aún confrontaban al visitante, pero no competían por la 
atención como lo hacían en el pasado. La disminución de la variedad con respecto a tamaño y forma creó una apariencia mucho más uniforme. Las disparidades evidentes en la inversión también disminuyeron, por lo que las marcadas divisiones del período anterior fueron silenciadas o estuvieron ausentes. Además, durante este tiempo una gran parte de los entierros ocurrieron en parcelas familiares en lugar de enterramientos aislados, como fuera común a fines del siglo XIX.

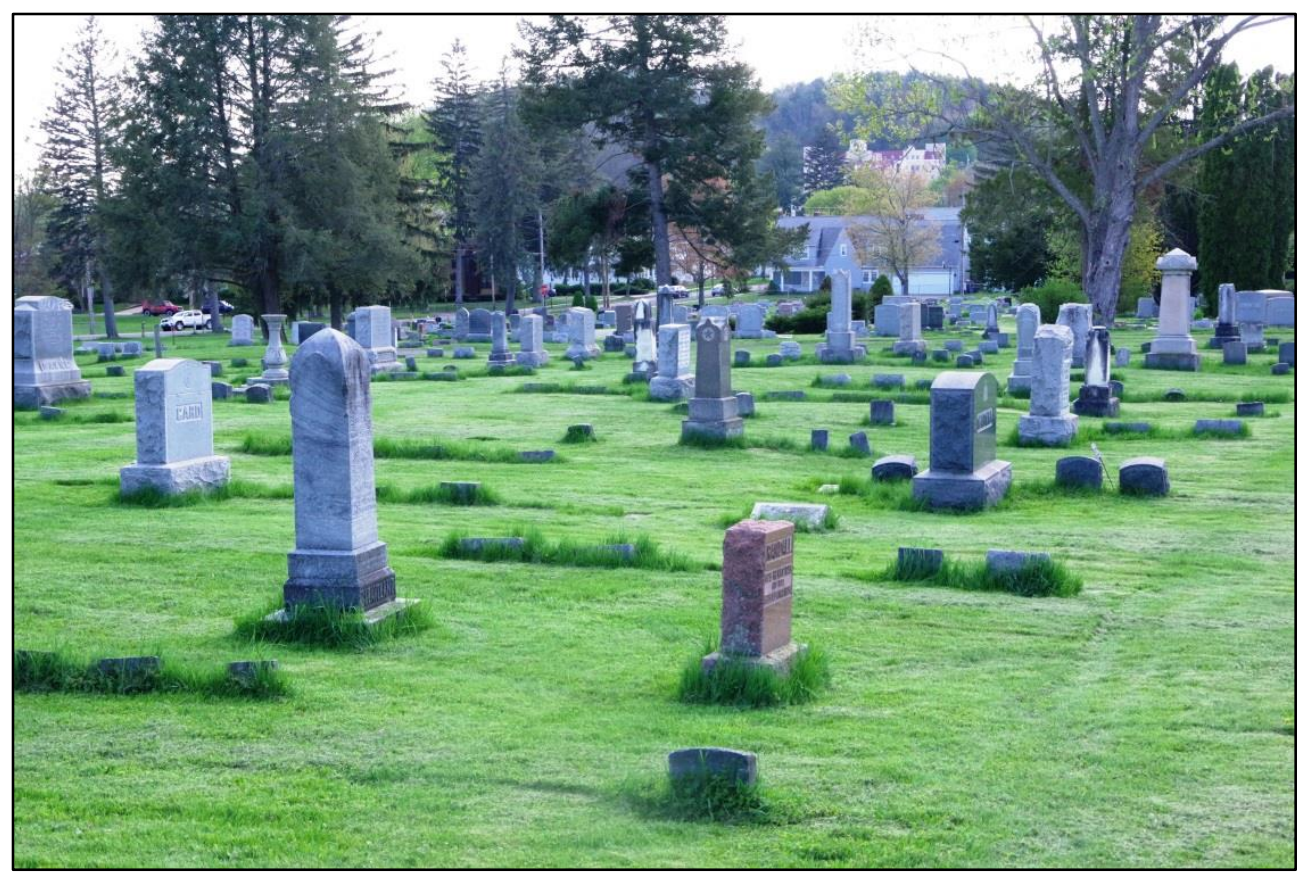

Figura 12: Un cementerio del período 1920-1940.

Un cementerio establecido en el condado de Broome en 1936 divergió radicalmente del modelo del cementerio parque que había regido a los cementerios establecidos hasta la década de 1920. Vestal Hills se construyó como un parque conmemorativo en el que los monumentos se limitaban a lápidas estandarizadas de bronce a nivel del suelo (Figura 13). Vestal Hills reflejó una tendencia nacional en la conmemoración, que había comenzado en otros lugares del país en la década de 1920 (Jackson, 1977). Esta tendencia enfatizó una forma socialmente discreta de disponer a los muertos y dominaría la segunda mitad del siglo XX en los cementerios del condado de Broome. 


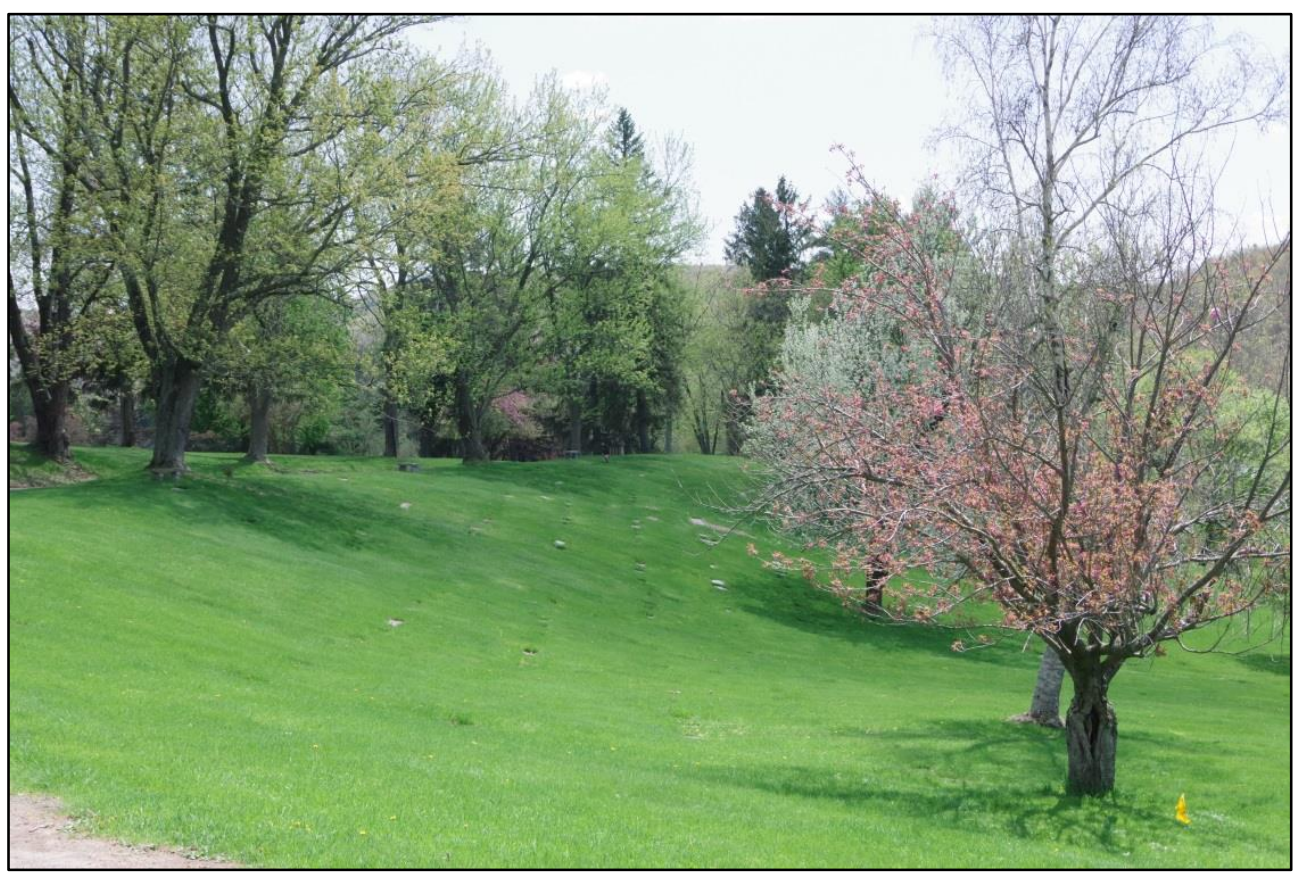

Figura 13: Vestal Hills, un parque conmemorativo.

Después de la Segunda Guerra Mundial, el tamaño y la cantidad de marcadores utilizados en el cementerio disminuyeron notoriamente. En la década de 1950, la parcela familiar rápidamente dejó de ser utilizada, y lo que hemos llamado parcelas de cónyuges se convirtieron en el tipo dominante de los grupos en el cementerio. Estas parcelas de cónyuges generalmente consistían en los entierros de marido y mujer, marcados por una sola lápida (Figura 14). La disminución en el tamaño, variedad y las diferencias en la inversión que comenzó en la década de 1920 se aceleró y culminó en los años de posguerra.

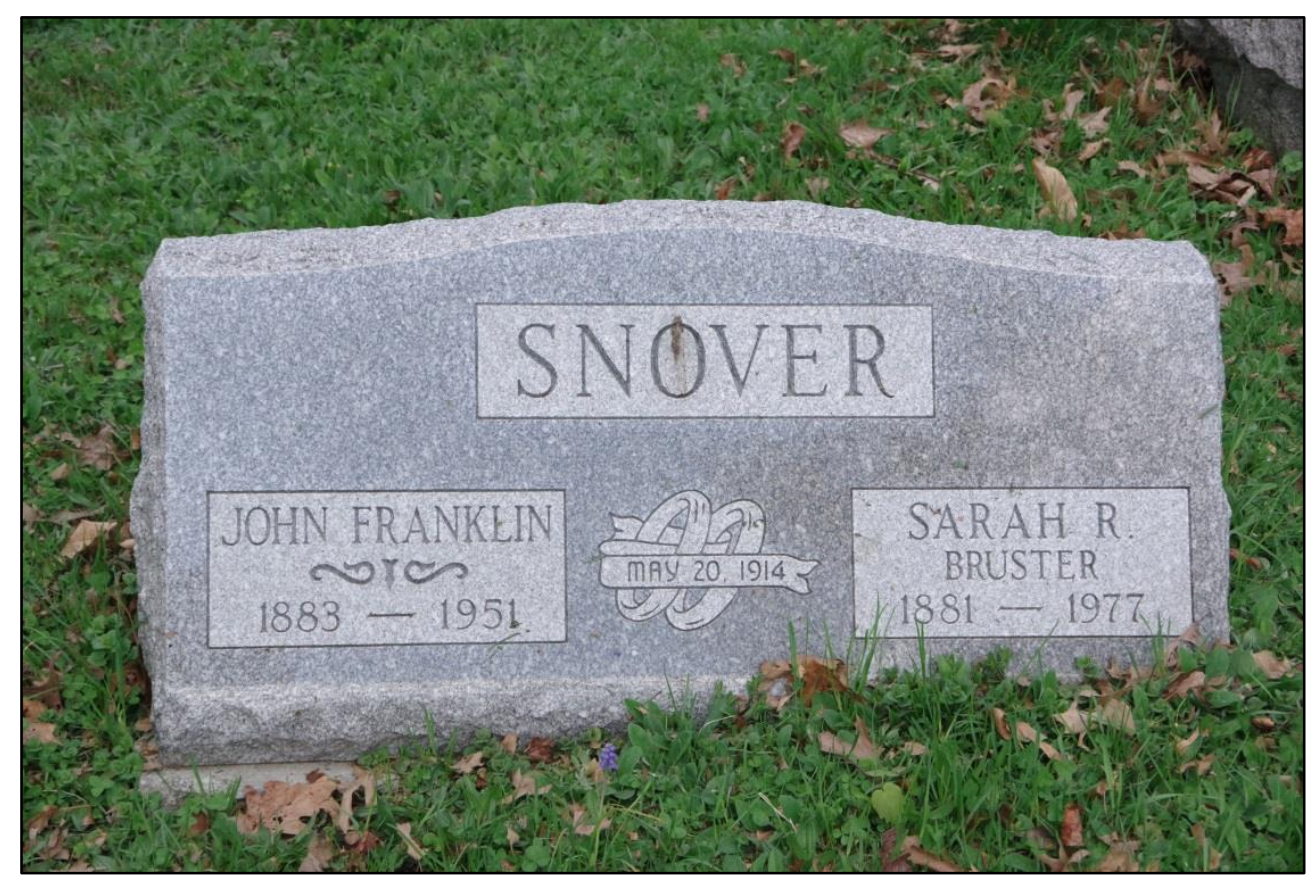

Figura 14: Una parcela de cónyuges de la década de 1950. 
Durante la década de 1940, la representación de la familia cambió para enfatizar la relación entre marido y mujer. La pareja estuvo unida para siempre en una sola lápida. A partir de finales de la década de 1950, muchas lápidas exhiben la fecha de matrimonio, además de las fechas de nacimiento y muerte de los individuos. A fines de la década de 1970, se produjo en el condado de Broome un renacimiento de los epitafios en las lápidas, conteniendo más comúnmente mensajes sobre el vínculo entre la pareja, por ejemplo, "Juntos para siempre". También en esa época, uno de los motivos decorativos populares fue una pareja caminando, tomada de las manos hacia el ocaso. Luego de la guerra, los infantes fueron enterrados cada vez más alejados de sus padres en una sección separada del cementerio. De vez en cuando, los niños mayores eran enterrados junto a sus padres, ya fuera con una lápida separada o con su nombre en la lápida de los padres.

La uniformidad del cementerio de entreguerras aumentó a medida que las lápidas se volvieron más bajas y menos variadas (Figura 15). Las lápidas no competían por la atención del visitante y se comunicaban principalmente con los miembros de la familia que venían a visitarlas; para otros, estaban perdidas en la masa de la uniformidad. La mayor expresión de esta uniformidad ocurrió en el parque conmemorativo y en los mausoleos públicos que se hicieron cada vez más populares en la década de 1960 (Figura 16). En ambas situaciones, lo único que diferencia un entierro de otro es el nombre individual y las fechas en el marcador. La manifestación última de uniformidad, la cremación, representó menos del 5 por ciento de los entierros del condado de Broome antes de 1980. Las personas de la comunidad que trabajan en funerarias, cementerios y en la fabricación de monumentos indican que la cremación está aumentando marcadamente en la década actual, y en el presente se aproxima al $20 \%$ de todos los entierros.

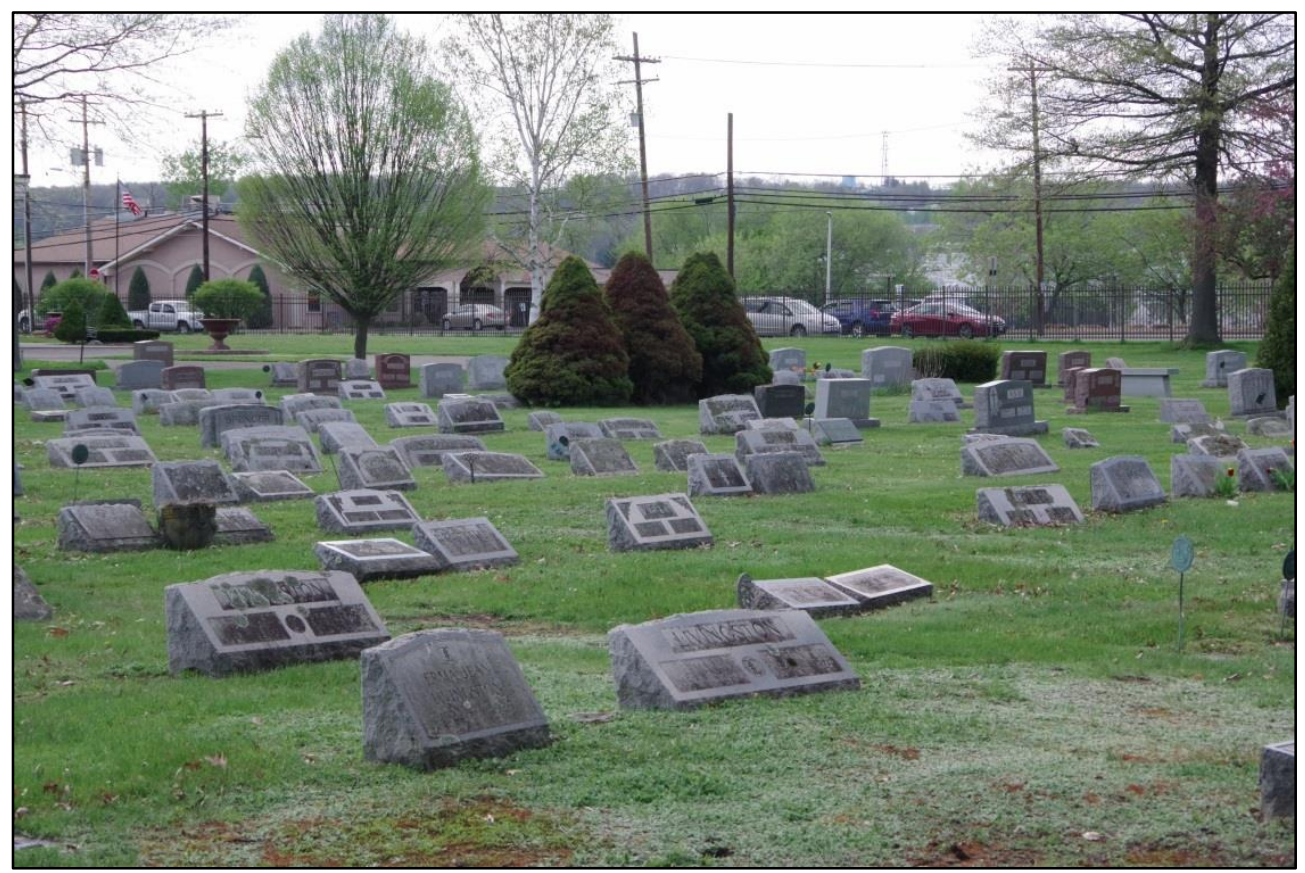

Figura 15: Un cementerio de 1950. 


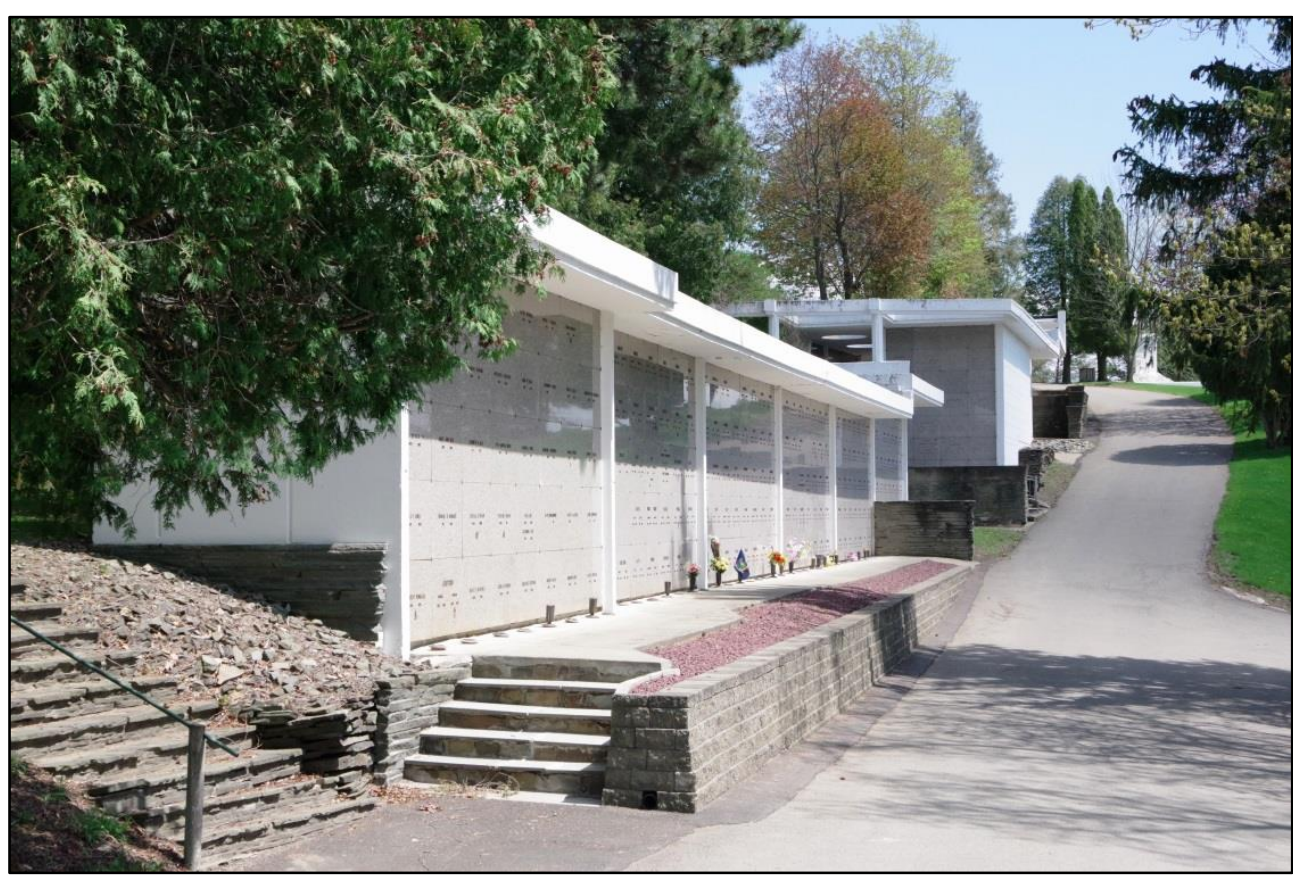

Figura 16: Un mausoleo público moderno.

Un tipo de individualidad producida en masa apareció en las lápidas de los últimos 20 años. Los marcadores a nivel del suelo e inclinados, relativamente uniformes, están cada vez más decorados con símbolos de pasatiempos e intereses personales tallados, como botes, pescadores, perros, automóviles, motocicletas y agujas de tejer. Ha habido un uso creciente de epitafios con frases religiosas fundamentalistas, seguidos en popularidad por expresiones de fidelidad marital.

En este último período, se produjeron desviaciones considerables del patrón general en los cementerios étnicos. Los cementerios de europeos del Este tienden a exhibir una mayor inversión en lápidas y una mayor variedad que las tumbas de irlandeses y protestantes. Los cementerios judíos no responden en absoluto a las tendencias generales, pero desde finales del siglo XIX en adelante se caracterizan por lápidas de granito gris de tamaño medio. La diferencia más sorprendente aparece en las lápidas italianas, que son más grandes y elaboradas después de la guerra, y a menudo incluyen estatuas (Figura 17). Las familias italianas también erigieron los 8 mausoleos privados levantados después de 1940 (Figura 18), y una familia que construyó un mausoleo en este período fue presidida por un zapatero. 


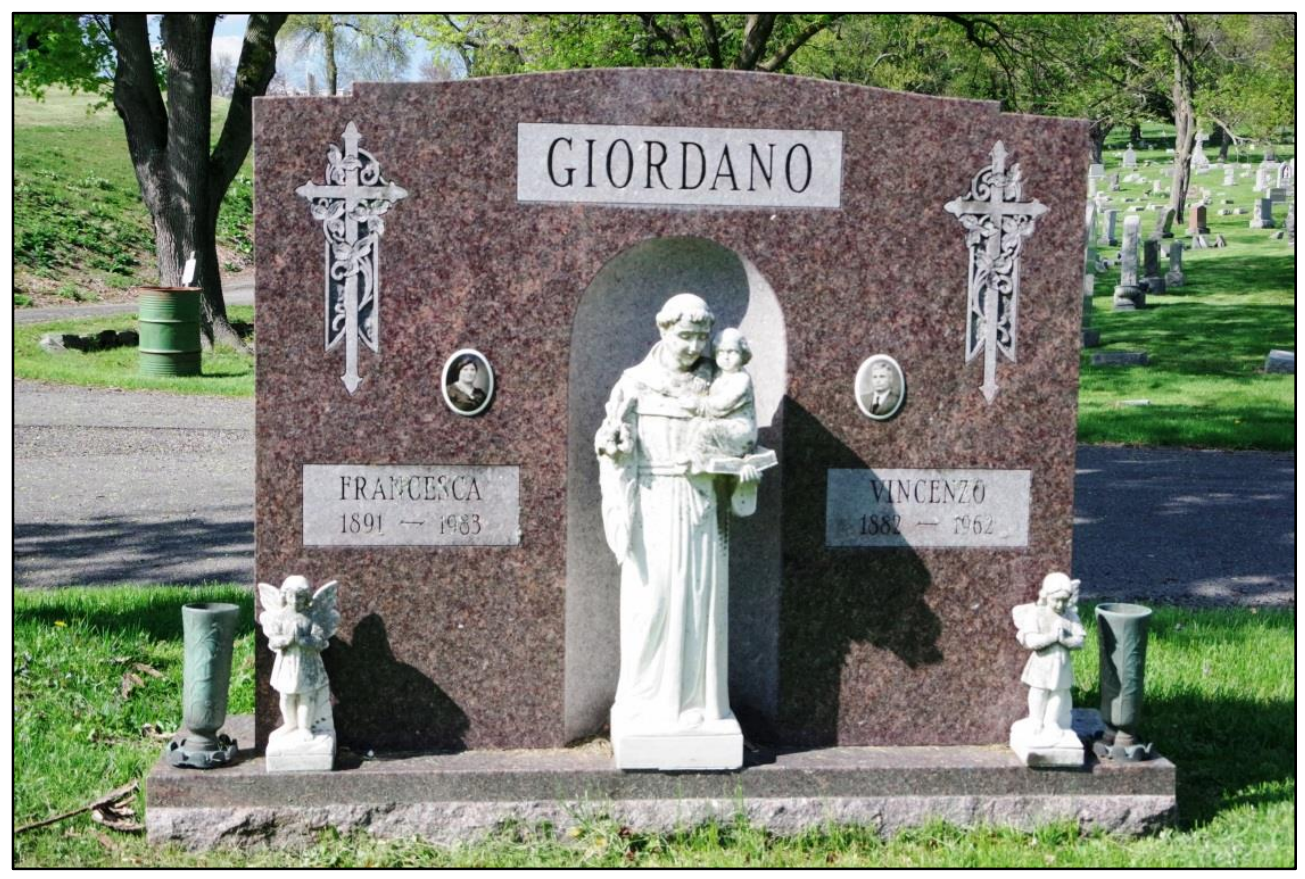

Figura 17: Monumentos conmemorativos italianos-estadounidenses de la década de 1960.

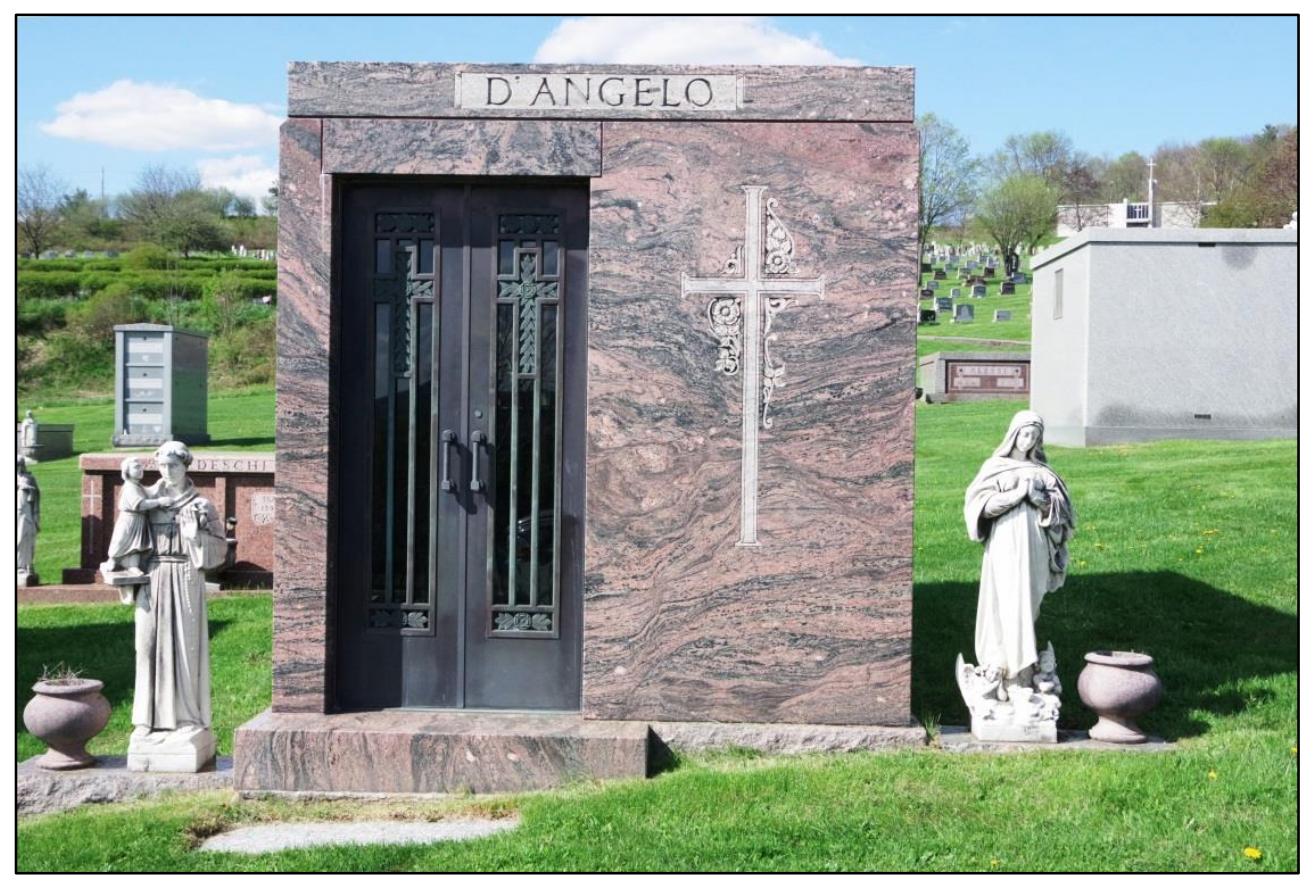

Figura 18: Mausoleos modernos de italianos-estadounidenses.

Desde la década de 1920 hasta la actualidad, los cementerios del condado de Broome no han reflejado directamente la estratificación social en la región. La distorsión de la realidad social es muy compleja. Las relaciones de la vida no son simplemente invertidas, ni tampoco el cementerio pierde significado en lo que respecta a los vivos. También se debe recordar que el paisaje moderno incluye todas las formas discutidas aquí. En algunos casos, las formas que he enumerado se pueden encontrar una al lado de la otra en un mismo cementerio. Los residentes del condado de Broome se enfrentan constantemente con lo viejo y lo nuevo en 
los cementerios, y el diálogo que resulta es una interacción compleja entre estos monumentos conmemorativos y los vivos.

\section{El CEMENTERIO y LA ElABORACIÓN DE LA IDEOlOGÍA}

Los cementerios del condado de Broome se construyeron como paisajes culturales significativos y reúnen aspectos aparentemente diferentes de la cultura e ideología. En cada período, los cementerios proporcionaron una forma material que afirmó y legitimó la ideología dominante de ese momento. A principios del siglo XIX, el cementerio negaba la existencia de desigualdades en la comunidad; a fines del siglo XIX y en el siglo XX se naturalizaron las desigualdades existentes en base a una glorificación del éxito individual; y a mediados del siglo XX se negó la existencia de diferencias cualitativas entre los individuos. El cementerio ha sido un participante activo en la creación, mantenimiento y recreación de estas ideologías a través de las percepciones de los vivos. Un examen detenido de la ideología dominante en los cementerios revela que a menudo estaba fracturada por la competencia dentro de la élite, y que las clases trabajadoras del condado de Broome a menudo la reelaboraban para formar sus propias ideologías.

\section{El CEMENTERIO COMO UnA EXPRESIÓN DE LA IDEOlogía DOMINANTE}

El cementerio del condado de Broome de principios del siglo XIX dispuso de los muertos para crear la comunidad ideal que los vivos nunca podrían alcanzar. La cerca que rodeaba el cementerio separaba en la muerte al que era miembro del que no lo era y afirmaba este contraste para los vivos. Dentro del cementerio existía una distinción entre marido y mujer, adulto y niño, pero no entre las unidades familiares que constituían la comunidad. Las desigualdades y las relaciones de poder dentro de la comunidad fueron oscurecidas en la muerte, negando su efectividad entre los vivos al declararlas manifestaciones transitorias y fugaces de esta vida, que debían abandonarse en la vida mejor que les aguardaba. El cementerio creó la apariencia de una igualdad entre los muertos, y ello confirmó a la ideología que enmascaró las relaciones de poder entre los vivos.

El cementerio también expresó la certeza de la muerte y la promesa de redención (Saum, 1975; Farrell, 1980). Las lápidas blancas en el cementerio fueron claramente visibles y observadas diariamente por la gente de la comunidad. Los epitafios hablan de escapar de los problemas de este mundo hacia las glorias del siguiente. También señalan que el fallecido esperaba reunirse con sus familiares y seres queridos en el más

allá. Por ejemplo, "Descansa, Jacob, descansa. Cuando nosotros al igual que tú hayamos pasado por el lúgubre viaje de la vida, vendremos y apoyaremos nuestra fatigada cabeza cerca de ti sobre el mismo dulce lecho". El sauce que se exhibía tan prominentemente en muchas lápidas era un símbolo de muerte y luto, pero también un símbolo bello y atrayente (Linden, 1980). La finalidad de la muerte también fue oscurecida, porque el cementerio expresó que la ardua vida corporal era fugaz, y la vida verdadera que aguardaba en la eternidad era bella y plácida.

Los cementerios del condado Broome de finales del siglo XIX son sorprendentemente diferentes de sus predecesores. Una plétora de monumentos de diferentes formas y alturas variadas confrontan al espectador. Grandes monumentos de granito, a veces coronados con estatuas de mármol y altos obeliscos, dominan el 
campo visual. La uniformidad ordenada y plácida del cementerio fue reemplazada por una mezcla disonante de imágenes que compiten entre sí. La realidad así creada enfatizaba las desigualdades en la comunidad.

La expansión del capitalismo y la industrialización a mediados del siglo XIX en América trajo consigo una transformación en la ideología, en la que participó el cementerio. La nueva ideología destacó la realización personal y se desarrolló en la última parte del siglo como doctrina del darwinismo social (Conwell, 1905; Sumner, 1963). El sistema de desigualdad fue naturalizado a través del modelo de éxito individual. El éxito era posible para todos, y los determinantes del éxito radicaban en las características de los individuos, negando así los determinantes sociales del éxito tales como la herencia, socialización, educación y conexiones sociales (Epstein, 1981; Sochen, 1981). El trabajo duro, austeridad, inteligencia, sobriedad, aseo y un poco de suerte garantizaban el éxito; mientras que el fracaso se debía a la falta de estas características o, más importante aún, a sus antagónicos -pereza, extravagancia, estupidez, dejadez y embriaguez.

Durante el siglo XIX, la separación creciente entre trabajo y hogar producida por el empleo en el sector industrial dio lugar a una ideología llamada el culto a la domesticidad. El hogar se convirtió en la esfera de las mujeres y en un refugio para el marido ante su lucha por el éxito en el mundo exterior (Strasser, 1982). A las mujeres les correspondía alimentar a sus maridos e hijos y mantener un entorno moral frente a un mundo exterior competitivo (Stowe, 1865). Para ello, las mujeres debían ser protegidas de la corrupción y la inmoralidad del mundo por sus maridos, quienes como proveedores y protectores ejercían el dominio patriarcal del hogar. En el mundo del comercio y el trabajo, la posición del marido pudo haber estado sujeta a constantes desafíos y amenazas, pero en el refugio de su hogar su autoridad no debía ser cuestionada. El dominio del marido dentro de la familia se naturalizó en referencia a la función biológica y económica.

Los elementos materiales no fueron pasivos en la creación y sustento de esta ideología de finales del siglo XIX porque proporcionaban la realidad objetiva que la volvía opaca. Las diferencias materiales separaban a aquéllos que habían tenido éxito de aquéllos de menor carácter y habilidad que habían fallado. Los que fracasaban vivían en barrios pobres, poseían pocas cosas de valor o ninguna, dilapidaban lo que ganaban en bebidas alcohólicas y violaban la santidad del hogar al enviar a sus esposas e hijos a las minas, molinos y fábricas. Por otro lado, los individuos de clase media y alta que tenían éxito, lo obtenían a través de hogares, trabajo y un consumo conspicuo de bienes (Veblen, 1899). Este consumo de la clase media y alta, a su vez, impulsó la expansión de la producción capitalista de los bienes de consumo. La ideología se originó en las duras diferencias materiales entre clases y las perpetuó.

Desde mediados del siglo XIX a principios del siglo XX, el cementerio participó y legitimó la ideología del darwinismo social. El cementerio comunitario, con su igualdad entre los muertos, no era apropiado para los nuevos adelantos. A principios del siglo fue rechazado por sucio, insalubre y antiestético. El movimiento del cementerio jardín de los años 1830 y 1840 intentó transformar al cementerio en un ideal romántico, al regresar a los muertos y a los vivos a la naturaleza, igualdad básica de los individuos. Sin embargo, el cementerio jardín otorgó la propiedad de las parcelas a los individuos, y los ideales románticos de igualdad pronto dieron paso a una feroz competencia entre familias, evidenciada en la majestuosidad de sus monumentos conmemorativos. El posterior movimiento de cementerio parque de la década de 1860 sufrió la misma transformación, debido a que dichos cementerios se convirtieron en "agrupaciones basadas en el dinero" (Farrell, 1980).

A pesar de que las parcelas fueron propiedad individual a fines del siglo XIX, los cementerios en sí fueron esencialmente espacios públicos. Los ciudadanos del siglo XIX usaron los cementerios tanto como 
nosotros ahora usamos los parques para realizar caminatas, excursiones y meditación (Fallows, 1885, French, 1975, Farrell, 1980). El cementerio de finales del siglo XIX y principios del siglo XX fue tanto un lugar para los vivos como para los muertos. Las familias que construyeron monumentos lo hicieron sabiendo que serían observados, examinados y comentados. No eran declaraciones privadas o íntimas, sino muy públicas. Estas declaraciones fueron la culminación y el producto último de las competencias por la riqueza y poder en las que los miembros de la familia habían participado lo largo de sus vidas. La ideología del darwinismo social fue afirmada en el paisaje del cementerio, donde las apariencias de éxito y fracaso fueron tan reales como en la vida.

La principal responsabilidad del éxito de la familia recayó sobre el patriarca y la parcela familiar proporcionó la declaración final de sus logros. Los monumentos conmemorativos en las parcelas recrearon las relaciones idealizadas de la familia. El marcador central altamente visible estableció las relaciones de la familia con el mundo exterior. Exaltó la posición del esposo como proveedor y protector y recordó el rol de la mujer como esposa, brindando apoyo moral y material para el esposo. Las relaciones de parentesco de la familia se expresaron en las lápidas menos visibles que designaban al padre, la madre, el hijo y la hija. La parcela familiar recreó en el cementerio el culto a la domesticidad que estructuró a la familia de clase media y alta en vida.

El cementerio legitimó el éxito y reforzó los orígenes naturales de la desigualdad. Así como los pobres no podían vanagloriarse del consumo o mantener la santidad de sus hogares en vida, tampoco en la muerte. A menudo no podían construir monumentos conmemorativos o se vieron obligados a construir monumentos menores. Por lo general, no podían comprar una parcela familiar, por lo que los miembros de la familia se dispersaban por el cementerio y la monumentalización requerida por el culto a la domesticidad estaba ausente en la muerte, al igual que la realidad del culto había estado ausente en la vida. Los cementerios del condado de Broome a fines del siglo XIX y principios del siglo XX no declararon las desigualdades transitorias y fugaces de la vida, como lo había hecho el cementerio previo, sino que las declararon como el orden natural de las cosas y las preservaron por tiempo inmemorial.

A comienzos del siglo XX, el capitalismo estaba en crisis; es decir, los principios operativos de la economía corrían peligro de derrumbarse (Mandel, 1978). La clara segregación de clases, el abuso a los trabajadores y el conflicto laboral habían producido la militancia más fuerte y radical en la historia del trabajo estadounidense (Amsden, 1979; Guèrin, 1979). Los sindicatos pidieron no sólo mejoras en las condiciones de trabajo sino también el establecimiento de una economía socialista. En 1917, la revolución bolchevique se enfrentó al capitalismo por primera vez con la realidad de un estado socialista. El radicalismo alcanzó su punto máximo en las huelgas de 1919, que fueron brutalmente reprimidas y seguidas por el infame "temor a los rojos" (Guèrin, 1979).

La industria de finales del siglo XIX se había construido principalmente por la expansión de los medios de producción (construcción de ferrocarriles, fábricas, molinos y maquinaria) y, en segundo lugar, por la producción de bienes de consumo para las clases medias y altas (Ewen, 1976; Mandel, 1978). A fines de dicho siglo, estos mercados se habían saturado y el capitalismo enfrentaba una crisis de realización. Para poder sobrevivir, las industrias de los Estados Unidos tenían que producir mucho más de lo que el mercado existente podía consumir. Esta crisis se reveló en la gran depresión de 1893 y en la caída de las tasas de ganancias desde la década de 1870 hasta 1900 (Mandel, 1978). 
La solución a esta crisis consistió en la introducción de la producción en masa y la creación de una nueva ideología, que al mismo tiempo fue producto y productora de la alteración de la sociedad provocada por la misma producción en masa. La producción en masa apareció por primera vez en 1910 cuando Henry Ford reorganizó su planta automotriz como una línea de ensamblaje (Chandler, 1967; Meyer, 1981) y la nueva ideología se desarrolló a principios de la década de 1920, mayormente por la publicidad (Ewen, 1976). La producción no se correspondió con la demanda creada por la ideología, y el nuevo orden no se cristalizó por completo hasta después de la Segunda Guerra Mundial (Ewen, 1976).

La producción en masa mediante el uso de máquinas altamente especializadas de un único propósito, operadas por trabajadores capacitados fácilmente, producía bienes a un costo menor y a tasas astronómicas en comparación con la producción de finales del siglo XIX (Ewen, 1976). Estos cambios hicieron que los bienes estuvieran disponibles para un segmento más amplio de la población y el número creciente de trabajadores semi-calificados y no calificados se convirtió en un mercado en expansión para bienes de consumo duraderos que antes solo podían comprar las clases altas y medias.

La producción en masa también redefinió la relación entre trabajadores y capital. Mientras que en el pasado los trabajadores habían sido principalmente una fuente de trabajo para los capitalistas, también se convirtieron en un mercado primario para la producción industrial (Nelson, 1975; Ewen, 1976). Esta transformación significó que los trabajadores necesitaban tiempo y mayores tasas de pago para consumir, y crédito para ampliar aún más ese poder adquisitivo. Los capitalistas expresaron la nueva relación en términos de un círculo funcionalmente integrado que benefició al capitalista con ganancias y al trabajador con bienes de consumo, sin explotar a nadie (Ford, 1929). Los nuevos profetas de la producción en masa culparon a las condiciones del pasado por una desviación de los principios democráticos del país y defendieron el retorno a los principios igualitarios que fundaron la nación (Carver, 1926).

Esta nueva ideología no abandonó todo el bagaje conceptual del pasado, sino que lo reformuló en el nuevo contexto. El culto al éxito individual siguió siendo una faceta central de la mistificación. El éxito y el fracaso aún se originaban en las capacidades de los individuos, pero cambió la definición de éxito. Mientras que antes todos los hombres tenían la oportunidad de tener éxito en el nuevo orden, ahora todos los hombres podían realmente alcanzar cierto éxito. La medida de un hombre ya no era el éxito o el fracaso, sino el grado de éxito.

La nueva ideología surgió en los años 1920 y creó su realidad. La identificación del éxito con el consumo conspicuo fue heredada del pasado. Con la difusión de la producción en masa, el consumo conspicuo se hizo posible para gran parte de la clase trabajadora. Una forma de fetichismo mercantil que se había creado en la segunda mitad del siglo XIX confundía las cosas materiales con las relaciones de estratificación (Veblen, 1899). Una vez que cambió la disponibilidad de las cosas, se creó la ilusión de un cambio en las relaciones humanas. En Middletown durante la década de 1920, las amas de casa de la clase trabajadora admitían que las clases habían existido en la comunidad durante su infancia porque sólo los ricos tenían autos, casas y lavarropas, pero ahora todos tenían estas cosas y solo existían diferencias de grado (Lynd \& Lynd, 1929).

Así como se transformó el ideal del marido, lo mismo sucedió con su esposa. La esposa se convirtió en la consumidora principal de la familia (Ewen, 1976; Matthaei, 1982). El nuevo ideal dio a las mujeres un papel público que articuló el hogar con el mundo exterior. Del mismo modo que se enfatizó la integración funcional del trabajador y el capital, también se enfatizó la integración funcional del marido y la mujer. Esto 
implicó una ideología que negaba el patriarcado del marido y acentuaba el vínculo emocional entre marido y mujer (Matthaei, 1982).

Vemos en los cementerios del condado de Broome durante el período de entreguerras la renegociación de la ideología y las relaciones sociales que tienen lugar en la sociedad en general. Los monumentos conmemorativos respondieron a las fuerzas de la producción en masa a medida que los avances en la tecnología para cortar las losas abarataron los monumentos conmemorativos, y el aumento de los salarios reales en la década de 1920 amplió el mercado para ellos. La marcada diferencia entre las clases en el cementerio comenzó a disminuir. Muchos de los ricos continuaron construyendo mausoleos y marcadores grandes, pero también lo hicieron las familias de menor estatus. Cada vez más familias pudieron establecer parcelas familiares y estas parcelas comunicaron la reconceptualización de la familia. El marcador central altamente visible sólo presentaba el apellido, mientras que las relaciones familiares permanecían en las lápidas más pequeñas.

La expansión de las parcelas familiares, con marcadores familiares, a un segmento más grande de la población desdibujó la distinción cualitativa entre éxito y fracaso, creando en el cementerio la misma diferenciación de grado que existía en otros ámbitos de la cultura material, como los hogares y automóviles. La competencia a través de los monumentos conmemorativos perdió significado a medida que más personas podían permitirse monumentos conmemorativos elaborados. Tal vez más importante, las familias de clase alta del condado de Broome que mantuvieron los patrones de consumo de finales del siglo XIX, incluyendo mausoleos y elaborados monumentos conmemorativos, fueron denigradas; mientras que aquéllos que adoptaron estilos de vida, hogares y monumentos conmemorativos menos pretenciosos fueron aclamados como líderes cívicos. Estas fuerzas trabajaron contra los ricos incrementando la competencia en el cementerio.

Después de la Segunda Guerra Mundial, la conmemoración de los muertos en los cementerios del condado de Broome ya no reflejó claramente la estratificación social en la comunidad, y los monumentos cada vez más se dirigieron a una audiencia íntima y no pública. Lo más llamativo en los cementerios con monumentos conmemorativos en pie es la uniformidad en el tamaño y la forma de los mismos. Los monumentos ya no compiten entre sí para llamar la atención del visitante, sino que se mezclan en una masa igualitaria. Las distinciones entre ellos en cuanto a los detalles en el diseño suelen ser muy personalizadas, pero no son visibles desde más allá de unos metros de distancia. El monumento y su decoración tienen un significado para una audiencia íntima de familiares y amigos que deben buscar la parcela. Las mercancías o las actividades mercantilizadas dominan los símbolos personalizados y proporcionan una identificación en los términos de consumo que caracterizaban al individuo. Los mausoleos públicos y los jardines conmemorativos brindan la máxima expresión del cementerio moderno. Aquí la uniformidad es extrema y sólo la búsqueda más cuidadosa ubica una parcela específica. En estos lugares de enterratorio, la existencia de distinciones de clase en la comunidad de los muertos se niega de manera más efectiva. Sólo quedan pequeñas diferencias de grado y emblemas de preferencia personal. En el cementerio moderno, los vivos encuentran una igualdad en la muerte que excede y valida la igualdad que perciben en la vida.

En los cementerios contemporáneos del condado de Broome, la familia prácticamente ha desaparecido siendo reemplazada por parejas casadas. La gran mayoría de las parcelas son parcelas de cónyuges en las que la pareja comparte la misma lápida y el mismo terreno. Sumado a la asociación espacial de la pareja, la 
decoración y los epitafios en las lápidas glorifican la relación de la pareja. El cementerio niega el patriarcado y crea en la muerte vínculos de matrimonio permanentes que las personas sólo pueden idealizar en vida.

El cambio hacia las parcelas de cónyuges no es explicable en términos de una mayor movilidad de las familias o la disminución de la mortalidad infantil. En el condado de Broome, las parcelas de cónyuges son preferidas incluso cuando las siguientes generaciones continúan residiendo en la comunidad y cuando los infantes o niños pequeños que mueren a menudo son enterrados en una sección especial para los niños del cementerio, y no con sus padres. Las parcelas de cónyuges reflejan y refuerzan la conceptualización de la familia como una unión integrada funcionalmente por un hombre y una mujer: "Juntos para siempre".

\section{El Cementerio como Fuerza Activa en la Ideología}

El cementerio moderno existe en un paisaje cultural que incluye a los cementerios de épocas anteriores $\mathrm{y}$, en algunos casos, los cementerios individuales incluyen secciones que representan todas las tendencias discutidas. Esencialmente existieron tres formas de cementerio y de conmemoración en el condado de Broome. Los cementerios de principios del siglo XIX pertenecían a las comunidades y minimizaban las desigualdades. Los cementerios de fines de siglo XIX y principios del siglo XX se organizaron como asociaciones y solidificaron las desigualdades en la muerte. Finalmente, desde la Segunda Guerra Mundial los cementerios han negado las desigualdades, la conmemoración se ha convertido en una declaración íntima y personal para familiares y amigos.

Desarrollando mi investigación en los cementerios de Binghamton, también me he comprometido por más de cuatro años con la observación participante de las costumbres sobre la muerte del condado de Broome. Mis visitas frecuentes al cementerio han dado lugar a muchas conversaciones con profesionales vinculados al negocio de los funerales, los monumentos conmemorativos y el cementerio, así como con ciudadanos comunes. He presentado mi investigación a una variedad de grupos civiles, eclesiásticos y de escuelas públicas. También hemos realizado entrevistas con docenas de personas de diferentes religiones y origen étnico. Todo esto me ha proporcionado una idea sobre cómo reacciona la gente del condado de Broome en relación a los monumentos conmemorativos de cada uno de los tres períodos, y cómo los cementerios contribuyen a la apariencia que mantiene la ideología moderna.

El observador moderno se enfrenta constantemente con los contrastes entre estas tres formas y debe mediar entre las ideologías en conflicto encarnadas en ellas. La realidad objetiva de estos cementerios aparentemente verifica la posición ideológica moderna promovida primero por los reformadores de la década de 1920, que vieron a la era victoriana como una aberración y vincularon el nuevo orden con los ideales románticos tempranos de los Estados Unidos. Para el ciudadano moderno del condado de Broome, los cementerios más antiguos con sus modestas señalizaciones blancas parecen pintorescos y capaces de evocar un tiempo más simple de comunidad y unidad, carente de la competencia y el conflicto que echan a perder el ideal moderno de igualdad. Los cementerios de finales del siglo XIX y principios del siglo XX, por otro lado, violan la ideología moderna. Parecen ostentosos, macabros y aberrantes. Los elaborados monumentos construidos para atraer al observador del siglo XIX y glorificar los logros y la ideología de los muertos repelen al visitante moderno. El contraste entre ellos, así como entre los más antiguos y contemporáneos, refuerza y recrea la ideología moderna en la mente del observador. 


\section{El Cementerio como Algo Distinto a una IDEOlogía Instrumentalista}

Los cambios en la ideología discutidos hasta ahora reflejan las tendencias generales o ideología dominante en la historia del condado de Broome. Esta ideología fue dominante tanto en el sentido de que fue la ideología de la élite de Binghamton, como en el sentido de que fue la fuente de la mayoría de los discursos ideológicos realizados en los cementerios. Los cementerios del condado de Broome, sin embargo, fueron mucho más que sólo una herramienta ideológica que la élite manipuló para promover su dominio. La ideología de cada momento fue compartida e interpretada de manera diferencial, y el cementerio también nos brinda acceso a algunos de estos procesos. Los cementerios del condado de Broome representaban los conflictos entre las élites rurales y urbanas de mediados del siglo XIX y la resistencia de los grupos étnicos de clase trabajadora del siglo XX.

A mediados del siglo XIX, la expansión de la producción industrial en Binghamton amenazó el bienestar económico y social de una élite rural que obtenía su riqueza y posición en parte por las actividades de manufactura rural (Wurst, 1986). Esta élite rural usó el reavivamiento de la religión y la estructura eclesiástica establecida en el Segundo Gran Despertar, que había ocurrido unos 30 o 40 años antes, para solidificar su identidad como grupo y tratar de conservar su posición y riqueza. Este esfuerzo infructuoso se manifestó en el uso del simbolismo del Segundo Gran Despertar en sus lápidas y en su manipulación en los cementerios rurales (Wurst, 1986).

En oposición a la estrategia de naturalizar las diferencias de clase por parte de las élites seculares, la élite rural buscó perpetuar una ideología de comunidad centrada en la religión que negaba la diferenciación de clases. La élite rural utilizó principalmente lápidas de mármol, en cementerios de la comunidad, que no se diferenciaban en tamaño y forma de las utilizadas por sus empleados, vecinos o familiares. Decoraron estas lápidas con el simbolismo del Segundo Gran Despertar (manos entrelazadas o señalando el cielo, anclas, Biblias, coronas y palomas) para reforzar y mantener una ideología religiosa. El simbolismo raramente ocurrió en los cementerios urbanos, dominados por grandes monumentos neoclásicos y barrocos de la élite urbana.

El uso de este simbolismo diferenció a la élite rural tanto de sus trabajadores como de la élite urbana. Las similitudes en forma y tamaño entre las lápidas de la élite rural y sus trabajadores negaban la diferencia de clase que los separaba, mientras que las diferencias entre los monumentos conmemorativos de las élites rurales y urbanas definían a la élite rural como algo separado de la urbana.

La ideología dominante de una relación mutuamente beneficiosa y funcional entre el capital y el trabajo fue reinterpretada y manipulada por los diversos grupos étnicos que integraban gran parte de la clase trabajadora del condado de Broome en el siglo XX (Zahavi, 1983). Las respuestas de estas personas a su posición subordinada se derivaron tanto histórica como culturalmente y no se redujeron a un proceso universal simple como la emulación (ver Miller, 1982).

La clase trabajadora del condado de Broome se organizó a sí misma con propósitos de apoyo mutuo, socialización, solidaridad y resistencia en función de su origen étnico (Clark, 1986). Crearon sus propias comunidades, con iglesias étnicas, tiendas, asociaciones y mercados para crear la realidad objetiva necesaria para mantener una cultura étnica. El establecimiento y el mantenimiento de un cementerio separado y un ritual mortuorio fueron un componente importante de esta cultura. Estas culturas étnicas se basaron en una ascendencia europea, pero la cultura fue recreada por la clase y experiencias históricas en Estados Unidos 
(Clark, 1986). Estas culturas étnicas fueron ideológicas porque proporcionaron un campo separado de la sociedad dominante en el que los individuos podían obtener el poder y la consciencia necesaria para resistirse a la sociedad dominante.

La conmemoración utilizada por los irlandeses establece un paralelo directo con el grupo dominante con alguna evidencia de una ligera emulación rezagada. Los irlandeses nunca construyeron monumentos conmemorativos que resultaran distintivos en cuanto a su forma de aquéllos de la sociedad dominante, sino que dependieron del simbolismo religioso católico y de un cementerio separado para distinguirse a sí mismos. Cuando los irlandeses se incorporaron a la clase media, perdieron el sentido de comunidad, y cuando llegaron nuevos grupos étnicos católicos a principios del siglo XX, su uso de las formas de cultura dominante también los identificó con la sociedad en general.

Entre mediados y fines del siglo XIX, cuando los irlandeses conformaban la mayoría de los católicos del condado, establecieron un cementerio parroquial separado. Existió una comunidad irlandesa bien definida y la solidaridad étnica proporcionó el principio organizativo para la huelga realizada en las fábricas de cigarros de toda la ciudad en 1890 que duró seis meses. Durante este tiempo, las tumbas de irlandeses eran similares a las tumbas de los protestantes de principios del siglo XIX, con lápidas dispuestas en hilera pertenecientes a un grupo familiar o individuos dispersos señalizados con lápidas. El uso de formas más antiguas y baratas de conmemoración fue el resultado de su pobreza relativa, mientras que la elección del cementerio y el uso de símbolos religiosos católicos establecieron una identidad irlandesa única.

A fines del siglo XIX y principios del siglo XX, cuando los irlandeses ingresaron a la clase media usaron parcelas familiares y mausoleos como los protestantes de clase media y alta. La inversión de los irlandeses en los monumentos conmemorativos alcanzó su punto máximo en la década de 1920, alrededor de 10 a 15 años después de los protestantes. Desde la Segunda Guerra Mundial en adelante, ha habido poca evidencia de una comunidad irlandesa coherente en el condado, y las tumbas de irlandeses son prácticamente indistinguibles de las tumbas de protestantes, excepto por el uso de cruces celtas y su presencia en cementerios católicos (Clark, 1986).

La variación en los cementerios judíos al principio reflejó la posición de diferentes grupos, pero como la mayoría de los judíos se incorporaron a las clases medias y altas, apareció una forma judía común de conmemoración que definió una frontera étnica y no de clase (Clark, 1986). Los judíos reformistas de clase media y alta de origen germánico utilizaron monumentos conmemorativos a fines del siglo XIX y principios del siglo XX, al igual que los protestantes de clase media y alta, con parcelas familiares y los mismos estilos de lápidas y decoraciones. Los judíos ortodoxos de la clase trabajadora provenientes de Europa del Este tenían lápidas angostas y altas como las de otros grupos de Europa del Este e italianos, y no utilizaron parcelas familiares, sino que enterraron a cada individuo por separado. A medida que estos judíos de Europa del Este se incorporaron a la clase media en la tercera y cuarta décadas del siglo $\mathrm{XX}$, los monumentos conmemorativos de las comunidades de Ortodoxos Reformistas y de Judíos Conservadores recién creadas se volvieron similares. Esta forma del cementerio judío con losas grises relativamente masivas dispuestas en parcelas de cónyuges continuó hasta la última década. Cada vez más en los últimos 10 años, los monumentos conmemorativos judíos no se pueden distinguir de los modestos monumentos conmemorativos de los protestantes y los irlandeses, a excepción de la estrella de David y el uso frecuente de epitafios hebreos.

Los europeos del Este y los italianos ingresaron en gran número por primera vez al condado de Broome en la primera mitad del siglo XX y la mayoría de ellos continúa integrando la clase trabajadora en la 
actualidad. En el siglo XX, la clase trabajadora estaba dividida por fronteras étnicas en vez de estar unificada por una etnicidad común como había sucedido con los irlandeses. Sin embargo, la solidaridad étnica y la acción colectiva se utilizaron para desafiar las prácticas de gestión. Por ejemplo, en la década de 1930, cuando la compañía EJ despidió a los trabajadores italianos de la curtiembre, la delegación local de los Hijos de Italia se enfrentó al presidente de la compañía y consiguió que los volvieran a contratar.

En las primeras tres décadas de este siglo las tumbas de estos grupos se presentan como enterramientos individuales en los bordes de los cementerios católicos, con una dispersión de monumentos muy modestos con tallados en lenguas nativas y a veces de una misma forma. En los años 1920 y 1930 se establecieron por separado una variedad de cementerios étnicos y comenzaron a aparecer parcelas familiares con marcadores centrales. Después de la Segunda Guerra Mundial, hubo un cambio en las parcelas de cónyuges, pero a diferencia de la preferencia protestante, la inversión en los monumentos conmemorativos aumentó en lugar de disminuir. Estos grupos tienden a utilizar motivos decorativos distintivos, tales como estatuas y fotos, que diferencian sus monumentos conmemorativos de los construidos por los irlandeses, judíos y protestantes. Los italianos conforman el único grupo que continúa construyendo mausoleos familiares desde la Segunda Guerra Mundial. Los individuos que erigen estas construcciones son líderes en la comunidad italiana y, por lo general, son contratistas (Clark, 1986).

Las manifestaciones materiales de la competencia de la élite y las culturas de la clase trabajadora, tales como los cementerios, tuvieron un rol activo en la negociación de las relaciones de poder en el condado porque proporcionaron una realidad material que objetivaba las divisiones entre los grupos que competían. La consciencia engendró esta objetivación y otros procesos de interacción fueron una condición a priori para la acción colectiva, como los intentos de la élite de prevenir la destrucción de la economía de producción rural y la huelga irlandesa de cigarros de 1890. Las diferencias discutidas en los cementerios desafiaron visiblemente la ideología dominante, pero también la reforzaron haciendo así realidad a los estereotipos de los grupos subordinados. Por ejemplo, los protestantes e irlandeses de clase media y alta consideran a los elaborados monumentos conmemorativos de los italianos como una evidencia ostentosa de su extravagancia y falta de buen gusto.

Enfatizar en las ideologías dominantes del condado de Broome en los siglos XIX y XX proporciona una comprensión de los cambios más prominentes en los cementerios del área, pero deja muchas anomalías sin explicación. El examen detallado de algunas de estas anomalías, incluidas las tumbas de la élite rural y los cementerios étnicos, revela que la ideología dominante fue fracturada y reformulada en ideologías de resistencia. Una noción instrumentalista de la ideología no necesariamente habría explicado estas prácticas y podría habernos negado el acceso a ellas.

La creación y recreación de los cementerios del condado de Broome como paisajes significativos implicaron más que un diálogo ideológico sobre las relaciones de poder. Los significados más evidentes en el cementerio se refieren a la muerte. Estos significados no son simplemente decoraciones sobre un velo ideológico, sino que forman parte de una estructura cultural mayor que incluye a la ideología. Los cambios en las creencias sobre la muerte estuvieron vinculados a los cambios en la ideología dominante en este nivel cultural mayor. 


\section{El Cementerio, la Cultura y la Muerte}

He argumentado que la ideología no es más que una pieza de un sistema cultural más amplio de ideas y creencias que estructuran el pensamiento. La cultura, según esta definición, es inherentemente mistificante porque un proceso de categorización específico que da sentido al mundo necesariamente enmascara u oculta el conocimiento que se revelaría a través de un proceso diferente de categorización. Los elementos específicos de este proceso pueden o no estar involucrados en la ideología, pueden o no ser manipulados consciente o inconscientemente en las relaciones de poder. La estructura más amplia de la cultura, sin embargo, continúa vinculando y afectando la forma de los elementos incluidos en la ideología.

Podemos ver estos vínculos en los cementerios del condado de Broome y usarlos para exponer las estructuras subyacentes a través de una consideración de los significados cambiantes de la muerte en este contexto. Estos cambios son paralelos a los cambios desde la naturalización a la negación en las ideologías de clase y familia, revelando una transformación cultural más fundamental desde un sistema de mistificación basado en la naturalización a fines del siglo XIX a uno basado en la negación en el siglo XX.

En el siglo XIX, los estadounidenses victorianos lidiaron con el dolor y conmoción de la muerte al establecer una relación continua con los muertos (Stannard, 1975; Jackson, 1977; Farrell, 1980). Esto se logró a través de una amplia variedad de prácticas y cultura material (Pike \& Armstrong, 1980). En la década de 1830 apareció una extensa literatura que incluía relatos de lechos de muerte ficcionales, extensos manuales de duelo, himnos y poemas (Douglas, 1975). Algunos ejemplos de esta literatura discutían desde cómo era el cielo hasta detalles como lo que se servía para el desayuno (Douglas, 1975). El cielo fue retratado como una extensión natural del mundo real en el que las relaciones y las realidades de la vida corporal continuaban pero de una forma más pura. Las escenas sobre el lecho de muerte (especialmente de madres o niños moribundos), lápidas, cementerios y escenas sobre el cielo fueron extremadamente comunes en el arte popular, y aparecían en las paredes de los recibidores, libros escolares y en muestrarios. También fueron populares las fotos del difunto en su ataúd, que la familia colgaba en las paredes de su hogar.

El cementerio representaba un puente que conectaba a los vivos y los muertos. El paisajismo y embellecimiento de los cementerios jardín y los cementerios parque proporcionaban un hogar perpetuo y agradable en el que la familia podía residir. La conmemoración de los muertos involucró un nuevo significado ya que representaba la conexión física y la continuidad de la familia. No recordar a la persona que había muerto significaba que la conexión con los vivos se rompería; sólo entonces la muerte sería una realidad. Por estas razones, los victorianos visitaron a menudo el cementerio y lo consideraron como una extensión natural del mundo de los vivos (Fallows, 1885).

La glorificación de la muerte no perduró hacia la primera mitad del siglo XX. Poco después del cambio de siglo, las costumbres victorianas fueron atacadas como mórbidas y derrochadoras. La nueva ideología que pasó a competirle la llamó "pornografía de la muerte” e intentó lidiar con la muerte negándola, removiéndola del mundo de los vivos (Gorer, 1955; Ariès, 1974, 1985; Becker, 1973). El conflicto entre estas dos creencias continuó hasta la década de 1930, cuando el periódico New York Times incluyó artículos elogiando las ventajas de la cremación, abogando por cementerios sencillos y criticando el costo indignante de los funerales (Roveland, 1984; Warner, 1959). El énfasis en el entierro se desplazó hacia formas económicas y "socialmente discretas" de disponer a los muertos (Jackson, 1977). Más recientemente, la actitud se manifiesta en las críticas a la industria funeraria que deplora el costo y la manipulación emocional del funeral, 
mientras que las extravagancias y las manipulaciones emocionales de las bodas que son similares no se cuestionan (Bowman, 1964; Mitford, 1963; Huntington y Metcalf, 1979).

Este cambio en el ritual de la muerte fue en parte permitido por la disminución de la tasa de mortalidad, especialmente entre los niños, y el incremento en el uso de hospitales para albergar a los moribundos (Huntington \& Metcalf, 1979). Estos cambios transformaron a la realidad de la muerte en una experiencia normal y han sido acompañados por negaciones de los rituales de la muerte. El difunto generalmente se embalsama hasta alcanzar una apariencia semejante a la que tenía en vida y se lo deja reposar en la "sala de los sueños" en el depósito de cadáveres alejado del hogar (Ariès, 1974). Luego del funeral, se desalientan los períodos prolongados de luto y el uso de negro en las actividades cotidianas considerándolos como mórbidos y perjudiciales para la recuperación del duelo (Huntington \& Metcalf, 1979).

El primer cementerio parque conmemorativo que apareció en el condado de Broome en la década de 1930 provee la expresión final de la negación de la muerte. El cementerio se asemeja a un campo de golf, excepto por el hecho de que el terreno es demasiado empinado. Los que pasan por allí no se enfrentan a los muertos a través de sus monumentos, sino que observan un césped verde y bien cuidado, con jarrones con flores dispersas.

Los cambios en el cementerio que crean la apariencia necesaria para la negación de la muerte son consistentes con los cambios que permiten negar las desigualdades de clase y género. La disminución en la inversión y la estandarización de los monumentos sirve a ambos. Éste no tiene que ser el caso. A principios del siglo XIX, fueron negadas las desigualdades en los cementerios del condado de Broome mediante el uso de lápidas de mármol blanco estandarizadas y muy visibles. Estas lápidas crearon una igualdad en el cementerio que no existía en vida, pero también afirmaron la certeza de la muerte. La finalidad de la muerte fue negada en los símbolos y epitafios en estos monumentos, que prometían una vida espiritual bendecida para toda la eternidad. En los últimos años, la forma del cementerio del condado de Broome resultó de y justificó la ideología existente y las creencias sobre la muerte. En ningún caso el paisaje cultural del cementerio se explica únicamente en términos de uno de estos sistemas de creencias. La ideología y la muerte deben alojarse mutuamente en el cementerio para mantener un mínimo grado de consistencia, de modo que las apariencias creadas por un conjunto de creencias no contradigan y desafíen al otro.

Me resulta difícil vincular convincentemente los cambios en las creencias que rodean a la muerte con los cambios en la economía capitalista de los últimos 150 años y/o las manipulaciones y renegociaciones de las relaciones de poder que acompañaron estos cambios. Ellos parecen conectarse con los cambios en la ideología que rodean a la familia y la estratificación en un nivel más básico y en un contexto cultural más general. Las similitudes entre estos sistemas de creencias y su expresión en los cementerios del condado de Broome sugieren un cambio en la estructura subyacente de la cultura y la mistificación inherente en la cultura. Esto ha producido un cambio desde la naturalización de aquellas cosas que son explotadoras, o en el caso de la muerte, traumáticas, hasta la negación de esas cosas. Esta transformación deriva de cambios en la naturaleza de la economía capitalista y los promulga, pero lo hace como parte de un todo cultural mayor. Esta conclusión apunta a la necesidad de un análisis cultural y social aún más amplio que el del cementerio, que fue el que se intentó aquí.

Los muertos del condado de Broome involucran a los vivos en un diálogo a través de los monumentos que erigieron y los paisajes culturales que crearon en los cementerios. Ellos no comunican de una manera simple y directa como muchos de nosotros, como arqueólogos, hemos querido interpretar. Nuestras 
suposiciones de que la exhibición mortuoria reflejará directamente el estatus no sólo son empíricamente incorrectas para el condado de Broome, sino que también nos niegan la capacidad de formular preguntas verdaderamente intrigantes que nos permitan descifrar la complejidad del discurso cambiante con los muertos.

La cultura y la ideología se encuentran en el centro de este discurso, y la fusión de las declaraciones acerca de la familia, la estratificación y la muerte en el cementerio proporcionan un vehículo para examinar el cambio en la estructura subyacente de la cultura y la ideología. Los muertos, sin embargo, pueden establecer el discurso pero no mantenerlo. El discurso finalmente debe continuar en la consciencia de los vivos, y los cambios en las condiciones materiales y las experiencias de los vivos afectan las formas que tomará el discurso. De este modo, el cementerio se convierte en un agente activo en las negociaciones sociales y el cambio cultural.

\section{AGRADECIMIENTOS}

Este trabajo es producto de un proyecto de investigación mayor que no podría haber sido completado sin la ayuda de otras personas que han trabajado en el mismo, incluidas Lynn Clark, Louann Wurst, Karlene Leeper y James Gibb. Las autoridades de los cementerios del condado de Broome han ayudado mucho a nuestro trabajo, especialmente Roger Cooper del cementerio Riverhurst en Endwell. Las conversaciones con Ted Dethlefsen, Robert Paynter, Catherine Lutz, Eric Wolf, Jane Collins y Meg Conkey fueron extremadamente útiles para mi formulación de este estudio. Numerosos individuos leyeron borradores previos de este trabajo y me proporcionaron valiosos comentarios, aunque no todos fueron incorporados, incluyendo a Susan Pollack, Tammy Bray, Andy Black, Jane Collins, Lynn Clark, Cynthia Woodsong, Ian Hodder, Sarah Elbert, George Cotkin, y Mark Leone. Parker Potter merece un agradecimiento especial por sus comentarios en el proceso de revisión. Louann Wurst me aportó la idea de que las ideologías dominantes y subordinadas no podrían funcionar de la misma manera. 


\section{REFERENCIAS BIBLIOGRÁFICAS}

ABERCOMBIE, N., HILL, S. \& TURNER, B. S. 1980. The Dominant Ideology Thesis. Allen \& Unwin, Londres.

ALTHUSSER, L. 1971. Lenin and Philosophy. Montly Review Press, Nueva York.

AMSDEN, J. 1979. Introduction. In GUEIN, D. (Ed.) 100 Years of Labor in the USA. Ink Links, Londres. Pp. 1-30.

ARIĖS, P. 1974. Western Attitudes towards Death from the Middle Ages to the Present. Johns Hopkins University Press, Baltimore.

ARIÈS, P. 1985. Images of Man and Death. Harvard University Press, Cambridge.

BARTEL, B. 1982. A Historical Review of Ethnological and Analyses of Mortuary Practices. Journal of Anthropological Archaeology, vol. 1, n 1:32-58.

BECKER, E. 1973. The Denial of Death. Free Press, Nueva York.

BENES, P. 1977. The Mask of Orthodoxy. University of Massachuset Press, Amherst.

BINDFORD, L. R. 1962. Archaeology as Anthropology. American Antiquity, vol. 28: 217-225.

BINDFORD, L. 1971. Mortuary Practices: Their Study and Their Potential. Society for American Archaeology, Memoirs, vol. 25: 6-29.

BLOCH, M. 1986. From Blessing to Violence. University of Cambridge Press, Cambridge.

BOWMAN, R. 1964. The American Funeral: A Study in Guilt, Extravagance and Sublimity. Paperback Library, Nueva York.

CARVER, T. N. 1926. The Present Economic Revolution in the United States. George Allen \& Unwin, Londres.

CHANDLER, A. D. 1967. Giant Enterprise, Ford, General Motors and the Automobile Industry. McGraw-Hill, Nueva York.

CLARK, L. M. 1986. Ethnicity in Binghamton Cemeteries. Tesis (Maestría), State University of New York, Binghamton.

CONWELL, R. H. 1905. Acres of Diamonds. Random House, Nueva York.

DARNALL, M. J. 1983. The American Cemetery as Picturesque Landscape: Bellefontaine Cemetery, St. Louis. Winterthur Portfolio, vol. 18:249-270.

DEETZ, J. \& DETHLEFSEN, E. J. 1978. Death's Heads, Cherub, Urn and Willow. In SCHUYLER, R. L. (Ed.) Historical Archaeology. Baywood, Farmingdale. Pp. 83-89.

DETHLEFSEN, E. J. 1977. The Cemetery and Culture Change: Archaeological Focus and Ethnographic Perspective. In GOULD, R. A. \& SCHIFFER, M. B. (Eds.) The Archaeology of U.S. Academic Press, New York. pp. 137-160.

DOUGLAS, A. 1975. Heaven Our Home: Consolation Literature in the Northern United States, 1830-1880. In STANNARD, D. E. (Ed.) Death in America. University of Pennsylvania Press, Filadelfia. Pp. 49-68.

EPSTEIN, B. L. 1981. The Politics of Domesticity. Wesleyan University Press, Middletown.

EWEN, S. 1976. Captains of Consciousness: Advertising and the Social Roots of the Consumer Culture. McGraw-Hill, Nueva York.

FALLOWS, D. D. 1885. The Home Beyond, or Views of Heaven and Its Relation to Earth. Fairbanks and Palmer, Chicago.

FARRELL, J. 1980. Inventing the American Way of Death, 1830-1920. Temple University Press, Filadelfia.

FORD, H. 1929. My Philosophy of Industry. Coward-McCann, Nueva York. 
FRENCH, S. 1975. The Cemetery as Cultural Institution: The Establishment of Mount Auburn and the "Rural Cemetery Movement”. In STANNARD, D. E. (Ed.) Death in America. University of Pennsylvania Press, Filadelfia. Pp. 69-91.

GIBB, J. G. 1985. Gravestones and Wakes: Binghamton's Funerary Industry Since 1860. Trabajo presentado en The 69th Annual Meeting of the New York State Archaeological Association, abril 19-21, Oneonta.

GODELIER, M. 1982. The Ideal in the Real. In SAMUEL, R. \& JONES, G. S. (Eds.) Culture Ideology and Politics. Routledge \& Kegan Paul, Londres. Pp. 12-38.

GORER, G. 1955. The Pornography of Death. Encounter, vol. 5: 49-52.

GRAMSCI, A. 1971. Selections from the Prison Notebooks. International Publishers, Nueva York.

GUERIN, D. 1979. 100 Years of Labor in the USA. Ink Links, Londres.

HANDSMAN. R. G. 1983. Towards Archaeological Histories of Robbins Swamp. Artifact, vol. 11, nº 3: 1-20.

HODDER, I. 1982. Theoretical Archaeology: A Reactionary View. In HODDER, I. (Ed.) Symbolic and Structural Archaeology. Cambridge University Press, Cambridge. Pp. 1-16.

HUNTINGTON, R. \& METCALF, P. 1979. Celebrations of Death: The Anthropology of Mortuary Ritual. Cambridge University Press, Cambridge.

JACKSON, C. O. 1977. Passing-The Vision of Death in America. Greenwood Press, Westport.

KRISTIANSEN, K. 1984. Ideology and Material Culture: An Archaeological Perspective. In SPRIGGS, M. (Ed.) Marxist Perspectives in Archaeology. Cambridge University Press, Cambridge. Pp. 72-100.

LARRAIN, J. 1983. Marxism and Ideology. Macmillan, Londres.

LEONE, M. 1986. Symbolic, Structural, and Critical Archaeology. In MELTZER, D. J., FOWLER, D. D. \& SABLOFF, J. A. (Eds.), American Archaeology Past and Future. Smithsonian Institution Press, Washington, D.C. Pp. 415-438.

LINDEN, B. M. G. 1980. The Willow Tree and Urn Motif. Markers, vol. 1: 149-156.

LUKACS, G. 1971. History and Class Consciousness. MIT Press, Cambridge.

LYND, R. \& LYND, H. M. 1929. Middletown. Harcout Brace Javanovich, Nueva York.

MANDEL, E. 1978. Late Capitalism. Verso, Londres.

MARX, K. \& ENGLES, F. 1947. The German Ideology. International Publishers, Nueva York.

MATTHAEI, J. A. 1982. An Economic History of Women in America. Shocken Books, Nueva York.

MEPHAM, J. 1979. The Theory of Ideology in Capital. In MEPHAM, J. \& RUBEN, D. H. (Eds.) Issue in Marxist Philosophy III. Humanities Press, Atlantic Highlands. Pp. 141-174.

MEYER, S. III. 1981. The Five Dollar Day. SUNY Press, Albany.

MILLER, D. 1982. Structures and Strategies: An Aspect of the Relationship between Social Hierarchy and Cultural Change. In HODDER, I. (Ed.) Symbolic and Structural Archaeology. Cambridge University Press, Cambridge. Pp. 89-98.

MITFORD, J. 1963. The American Way of Death. Simon and Schuster, Nueva York.

NELSON, D. 1975. Managers and Workers: Origins of the New Factory System in the United States 1880-1920. University of Wisconsin Press, Madison.

O’SHEA, J.M. 1984. Mortuary Variability: An Archaeological Investigation. Academic Press, Orlando.

PEARSON, M. P. 1982. Mortuary Practices, Society and Ideology: An Ethnoarchaeological Study. In HODDER, I. (Ed.) Symbolic and Structural Archaeology. Cambridge University Press, Cambridge. Pp. 99-114. 
PIKE, M. V. \& ARMSTRONG, J. G. 1980. A Time to Mourn: Expressions of Grief in Nineteenth Century America. Museum of Stony Brook, Stony Brook.

ROVELAND, B. E. 1984. Houses of the Dead: A Study of Mausoleums in the Binghamton Area. Harpur Academic Review, vol. 1: 47-70.

SAUM, L. O. 1975. Death in the Popular Mind of Pre-Civil War America. In STANNARD, D. E. (Ed.) Death in America. University of Pennsylvania Press, Filadelfia. Pp. 330-348.

SAXE, A. A. 1970. Social Dimensions of Mortuary Practices. Tesis (Doctorado), University of Michigan, Ann Arbor.

SHANKS, M. \& TILLEY, C. 1982. Ideology, Symbolic Power and Ritual Communication: A reinterpretation of Neolithic Mortuary Practices. In HODDER, I. (Ed.) Symbolic and Structural Archaeology. Cambridge University Press, Cambridge. Pp. 129-154.

SOCHEN, J. 1981. Herstory. A Record of the American Women's Past. Alfred Publishing Co, Sherman Oaks.

STANNARD, D. E. 1975. Death in America. University of Pennsylvania Press, Filadelfia.

STOWE, H. B. 1865. House and Home Papers. Ticknor and Fields, Boston.

Strasser, S. M. 1982. Never Done: A History of American Housework. Pantheon Books, Nueva York.

SUMNER, W. G. 1963. Social Darwinism: Selected Essays. Prentice-Hall, Englewood Cliffs.

TAINTER, J. A. 1978. Mortuary Practice and the Study of Prehistoric Social Systems. Advances in Archaeological Method and Theory, vol. 1: 106-143.

TASHJIAN, D. \& TASHJIAN, A. 1974. Memorials for Children of Change. Wesleyan University Press, Middletown.

VEBLEN, G. 1899. The Theory of the Leisure Class. George Allen \& Unwin, Londres.

WARNER, W. L. 1959. The Living and the Death. Yale University Press, New Heaven.

WHITE, L. 1959. The Evolution of Culture. McGraw-Hill, Nueva York.

WURST, L. A. 1986. A Rope of Sand: Second Great Awakening Symbolism on the Gravestones of the Rural Elite in Broome County, New York. Tesis (Maestría), State University of New York, Binghamton.

ZAHAVI, G. 1983. Negotiated Loyalty: Welfare Capitalism and the Shoeworkers of Endicott-Johnson, 19201940. Journal of American History, vol. 70, n 3: 602-620. 